\title{
Phosphorus in the Truckee River Between Vista and Patrick, Storey and Washoe Counties, Nevada, August 1984
}

By Ray J. Hoffman

\section{U.S. GEOLOGICAL SURVEY}

Water-Resources Investigations Report 89-4175

Prepared in cooperation with the NEVADA DEPARTMENT OF CONSERVATION AND NATURAL RESOURCES, DIVISION OF ENVIRONMENTAL PROTECTION

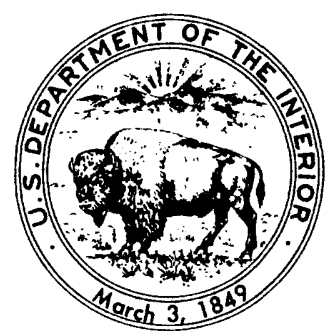

Carson City, Nevada 1990 
DEPARTMENT OF THE INTERIOR

MANUEL LUJAN, JR., Secretary

\section{U.S. GEOLOGICAL SURVEY}

Dallas L. Peck, Director

For additional information write to:

U.S. Geological Survey Room 227, Federal Building 705 North Plaza Street Carson City, NV 89701
Copies of this report may be purchased from:

U.S. Geological Survey Books and Open-File Reports Section Federal Center, Building 810

Box 25425

Denver, CO 80225 


\section{CONTENTS}

Page

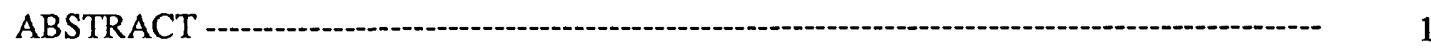

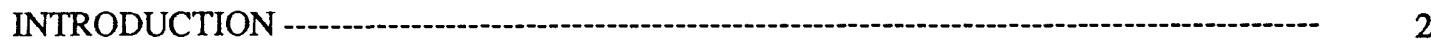

DESCRIPTION OF THE STUDY AREA -

SAMPLING METHODS AND ANALYSES -

WORKING HYPOTHESES REGARDING THE POSSIBLE CAUSE

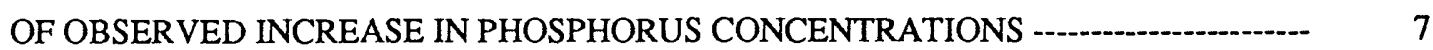

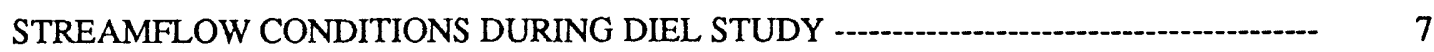

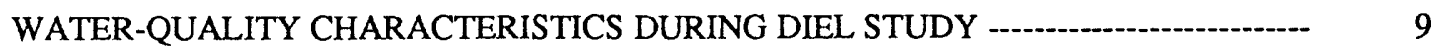

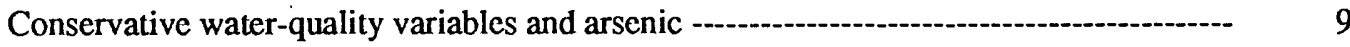

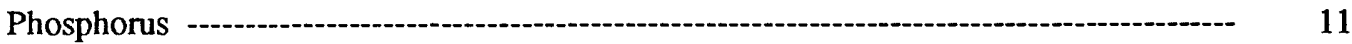

COMPARISON OF PREVIOUS DATA WITH THE RESULTS OF THIS STUDY

SUMMARY AND CONCLUSIONS

HYDROLOGIC DATA --- 27

REFERENCES CITED -

\section{ILLUSTRATIONS}

Figure 1. Map showing location of study area - 3

2. Sketch of study reach -

3. Graph showing instantaneous streamflow of river during diel study of August 15-16, 1984 --.-.-

4-6. Graphs showing phosphorus concentration in river during diel study of August 15-16, 1984, for true and adjusted sampling times:

4. Total phosphorus --ons

5. Dissolved phosphorus - - 13

6. Suspended phosphorus -.-.-.-.-.- 16

7. Bar graph showing mean concentrations of total, dissolved, and suspended

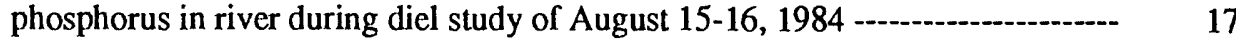

8-11. Graphs showing:

8. Total-phosphorus concentration in effluent from Reno-Sparks Wastewater

Treatment Plant during the diel study of August 15-16, 1984

9. Dissolved-oxygen concentration in river during the diel study of

August 15-16, 1984

10. Dissolved-oxygen saturation percentage in river during the diel study of August 15-16, 1984

11. Dissolved-phosphorus load in effluent from Reno-Sparks Wastewater Treatment Plant during the dicl study of August 13-14, 1980 


\section{TABLES}

Tables 1-4. Summaries for diel study of August 15-16, 1984:

1. Statistics on water-quality data and streamflow

2. Mean loads of chloride, sulfate, dissolved solids, and arsenic -.............. 11

3. Physical conditions at four sampling stations - - 14

4. Mean phosphorus loads -....- 17

5. Selected hydrologic data for reach from Vista to Tracy,

October 1977 through August 1984 -....- 28

6. Hydrologic data for diel study of August 15-16, 1984

\section{CONVERSION FACTORS AND ABBREVIATIONS}

"Inch-pound" units of measure used in this report may be converted to metric (International System) units by using the following factors:

\section{Multiply}

Cubic feet per second $\left(\mathrm{ft}^{3} / \mathrm{s}\right)$

Feet ( $\mathrm{ft}$ )

Feet per second $(\mathrm{ft} / \mathrm{s})$

Gallons (gal)

Miles (mi)

Pounds per day $(\mathrm{lb} / \mathrm{d})$

Square miles $\left(\mathrm{mi}^{2}\right)$
By

0.02832

0.3048

0.3048

3.785

1.609

0.4536

2.590

\section{To obtain}

Cubic meters per second $\left(\mathrm{m}^{3} / \mathrm{s}\right)$

Meters (m)

Meters per second $(\mathrm{m} / \mathrm{s})$

Liters (L)

Kilometers (km)

Kilograms per day $(\mathrm{kg} / \mathrm{d})$

Square kilometers $\left(\mathrm{km}^{2}\right)$

For temperature, degrees Celsius $\left({ }^{\circ} \mathrm{C}\right)$ may be converted to degrees Fahrenheit $\left({ }^{\circ} \mathrm{F}\right)$ by using the formula ${ }^{\circ} \mathrm{F}=\left[(1.8)\left({ }^{\circ} \mathrm{C}\right)\right]+32$.

\section{SEA LEVEL}

In this report, "sea level" refers to the National Geodetic Vertical Datum of 1929 (NGVD of 1929), which is derived from a general adjustment of the first-order leveling networks of both the United States and Canada (formerly called "Sea-Level Datum of 1929"). 


\title{
Phosphorus in the Truckee River Between Vista and Patrick, Storey and Washoe Counties, Nevada, August 1984
}

\author{
By Ray J. Hoffman
}

\begin{abstract}
During calibration of a numerical water-quality model of the Truckee River below Reno, Nevada, the modeling results showed an undocumented accretion of phosphorus between Lockwood and Patrick at streamflows of about 300 cubic feet per second. An examination of available historical data tended to support the observed increase.

In August 1984, at a streamflow of about 300 cubic feet per second, a diel sampling program was undertaken at four stations along a 7.3-mile reach of the river to determine if the undocumented input of phosphorus was real, or was due to errors associated with water-quality sampling procedures, or the river's traveltime, or both. Water samples were collected using the equal-discharge-increment method across the stream, for the analysis of phosphorus, chloride, sulfate, and arsenic. Onsite measurements included specific conductance, dissolved oxygen, water temperature, and $\mathrm{pH}$. All water-quality data were collected every 2 hours and instantaneous streamflow was measured about every 3 hours at each station.

The results of field work and a thorough analysis of past sampling programs in the Truckee River suggest that the apparent increase in phosphorus between Lockwood and Patrick was most likely the result of sampling protocol in association with the river's time of travel and compounded by fluctuating phosphorus loads from an upstream wastewater treatment plant near Reno during periods of moderate streamflow. During high streamflow conditions, the increase may also have been the result of the resuspension of particulate phosphorus.
\end{abstract}




\section{INTRODUCTION}

Phosphorus is a key element in the sustenance of all living things. At the cellular level, it provides the most important energy-rich bonds, such as those in adenosine diphosphate and adenosine triphosphate. By virtue of these remarkable multiple bonds, a source of abundant energy is stored and made available to drive all cellular processes, plant and animal alike (Paul, 1967, p. 51-76).

In the aquatic environment, phosphorus, existing primarily as dissolved phosphate, is an important indicator of the nutritional status of natural water because it contributes, in concert with certain other essential nutrients, to the excessive production of aquatic nuisance plants (for example, "algal blooms"). In contrast to carbon and nitrogen, phosphorus has a rather restricted biogeochemical cycle; that is, it has no comparable atmospheric source. Because of its molecular make up, phosphate in solution is rapidly sorbed to particulate matter (Hem, 1985, p. 126-128). Thus, phosphorus from natural sources commonly is found in only trace quantities in many surface waters and most ground water. Man-caused inputs of phosphorus to waterways, however, can be substantial and may result in excessive production of aquatic plants, in kind and quantity.

Controlling the discharge of phosphorus from the Reno-Sparks Joint Wastewater Treatment Plant to the Truckee River, is of concern to managers and downstream users in the lower Truckee River-Pyramid Lake system (figure 1). Recent analysis of available water-quality data from the river downstream from Reno showed that inputs or accretions of phosphorus to the river between Lockwood and Patrick appeared to be important. The significance of these undocumented loadings came to light during the calibration of the U.S. Geological Survey's Truckee River Water-Quality model (Nowlin, 1987). For example, calibration of the numerical model to observed Geological Survey synoptic data for August 1979 and August 1980 (La Camera and others, 1985) showed that nonpoint loads of about $540 \mathrm{lb} / \mathrm{d}$ and $360 \mathrm{lb} / \mathrm{d}$ would be required in the reach betwcen Lockwood and Patrick, respectively, to duplicate measured instream concentrations. [According to Nowlin (1987, p. 173-191) these results assume a constant assimilation rate of $0.25 / \mathrm{d}$, base e, at $20^{\circ} \mathrm{C}$, of phosphorus in the modeled reach.] Previous water-quality data that tend to support the apparent increase in concentration include those from the Pacific Environmental Laboratories study in 1977-78 (Pacific Environmental Laboratory, 1979); the Desert Research Institute monthly monitoring data; and the U.S. Geological Survey synoptic data in 1979-80 (La Camera and others, 1985).

The importance of the undefined inputs, if real, can be evaluated in terms of the present operation and future planning of the Reno-Sparks wastewater treatment plant. Each 0.1 -milligram-per-liter $(\mathrm{mg} / \mathrm{L})$ reduction of phosphorus concentration in the treatment-plant effluent costs about $\$ 31$ per day of additional operating expenses (John Gonzales, City of Sparks, oral communication, 1985). Final discharge limits set for the Master Project (U.S. Environmental Protection Agency, 1984, p. 18 and E-11), an upgraded treatment condition, specify that the effluent concentration not exceed $0.4 \mathrm{mg} / \mathrm{L}$. This concentration translates into a load of about $130 \mathrm{lb} / \mathrm{d}$ at $40 \mathrm{mgal} / \mathrm{d}\left(62 \mathrm{ft}^{3} / \mathrm{s}\right)$ in contrast to a possible $500 \mathrm{lb} / \mathrm{d}$ input from an "unknown" source. If the unknown source were indeed real, then the difference in load would allow a relaxation of the permit requirement of the National Pollutant Discharge Elimination System for removal of phosphorus from the Reno-Sparks wastewater treatment plant. 


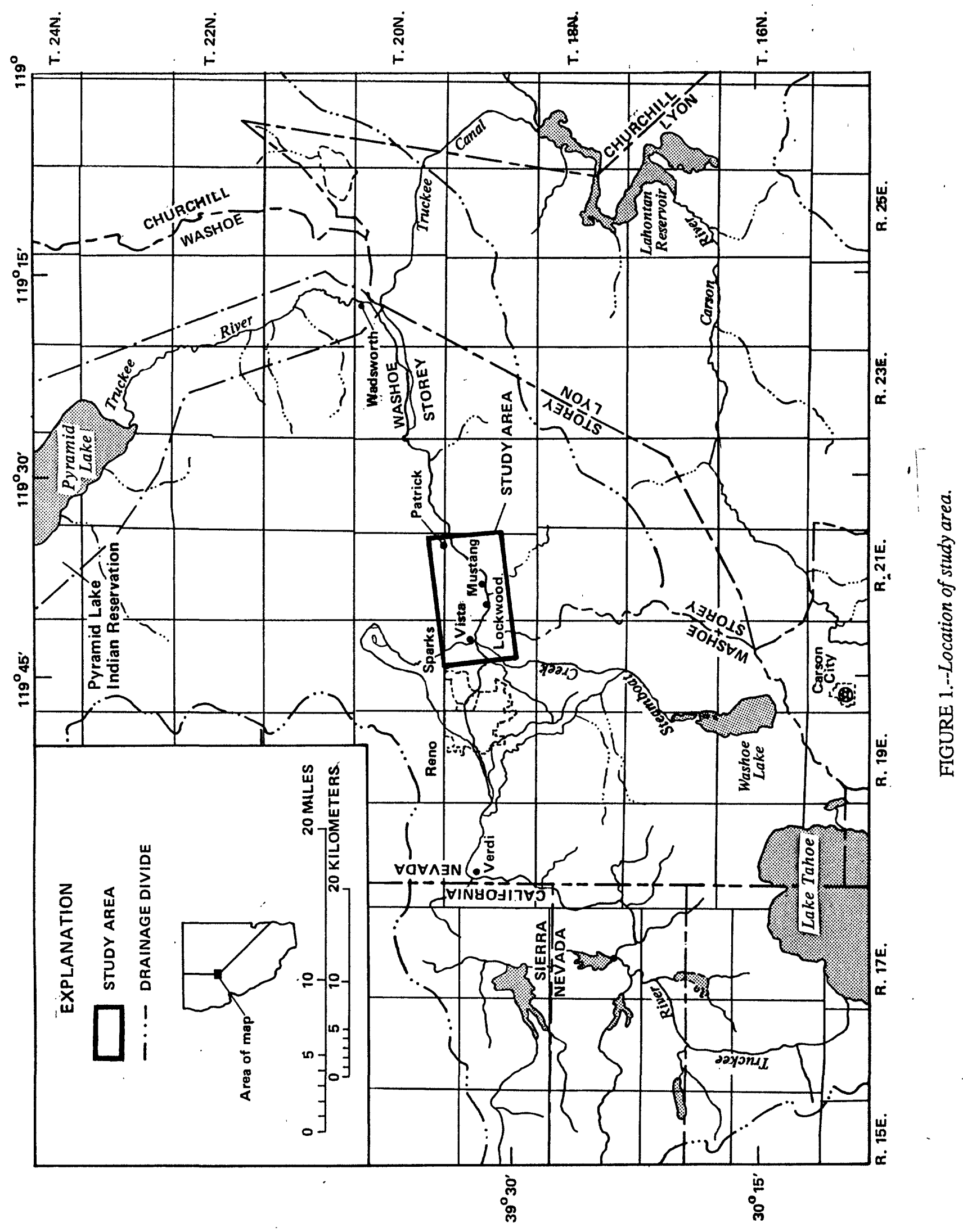


Apart from the possible economic effect on the Cities of Reno and Sparks, the identification and quantification of such an input would have strong technical and scientific ramifications in relation to the ongoing water-quality and fishery issues in the lower Truckee River and Pyramid Lake. In this regard, the Nevada Division of Environmental Protection, which has the primary responsibility for the coordination and control of the State's water quality, requested that the U.S. Geological Survey make a short-term reconnaissance study of phosphorus in the reach of the Truckee River from Lockwood to Patrick. The study was initiated by cooperative agreement, and field work spanned a 25-hour period during August 15-16, 1984.

The purpose of the study was to determine whether the observed accretions of phosphorus between Lockwood and Patrick, as suggested by previous data, were real, or instead were an artifact caused by measurement error or the effect of time of travel, or both. The scope of the study included frequent sampling and measurements of selected hydrologic variables at four stations along a 7.3-mile reach downstream from Reno over a 25-hour period (a diel ${ }^{1}$ ). The sampling stations (figure 2); listed in the downstream direction, were at the Vista gage (R.M. 52.23), Lockwood (R.M. 50.05), Mustang (upstream bridge at R.M. 48.25), and Patrick near McCarran Ranch (R.M. 44.92); the abbreviation R.M. indicates "river mile."

This report presents the results of the hydrologic-data-collection effort of August 15-16, 1984. Also presented is a comparative analysis of the phosphorus data collected at that time and data collected previously in the Truckee River.

A special acknowledgment is made to Allen Biaggi, Ralph G. Capurro, and James J. Cooper of the Nevada Division of Environmental Protection, and Leonard E. Crowe of the Washoe County Department of Comprehensive Planning, for their noteworthy around-the-clock assistance in the field during this study.

\section{DESCRIPTION OF THE STUDY AREA}

The Truckee River originates at the outlet of Lake Tahoe, Calif., at an altitude of about 6,230 feet above sea level (figure 1). Within a mixed coniferous forest, the river flows through a steep canyon that trends generally northward. Near Verdi, Nev., the river turns eastward and begins its journey into the rain shadow of the Sierra Nevada. With reduced gradient and water clarity, the river passes through the urban areas of Reno and Sparks. Here the river receives treated domestic sewage from the cities' jointly owned wastewater treatment facility. The outfall of treated sewage (average monthly flow of about $34 \mathrm{ft}^{3} / \mathrm{s}$ ) discharges to Steamboat Creck 0.13 mile upstream from the confluence of the Truckec River. Downstream from Sparks, the Truckee River continues eastward through a semidesert of sand and sagebrush to Wadsworth, where it turns northward and eventually empties into mildly saline Pyramid Lake at an altitude of about 3,800 feet. The length of the river from Lake Tahoe to Pyramid Lake is 116 miles, with a drainage area of $432 \mathrm{mi}^{2}$.

The 7.3-mile reach from Vista to Patrick, at a streamflow of $300 \mathrm{ft}^{3} / \mathrm{s}$, can be characterized thus: moderate velocity (less than $2 \mathrm{ft} / \mathrm{s}$ ), fairly narrow (about 100 feet from bank to bank), and shallow (depths commonly less than 3 feet). The streambed consists mainly of cobbles and boulders that are often covered with a luxuriant film of periphyton (mainly algae). The riparian vegetation consists principally of dense stands of willows and sparse cottonwood trees. The limbs of willows overhang the river banks from place to place along the study reach.

${ }^{1}$ Diel measurements are those involving a 24 -hour period that includes a day and adjoining night. 


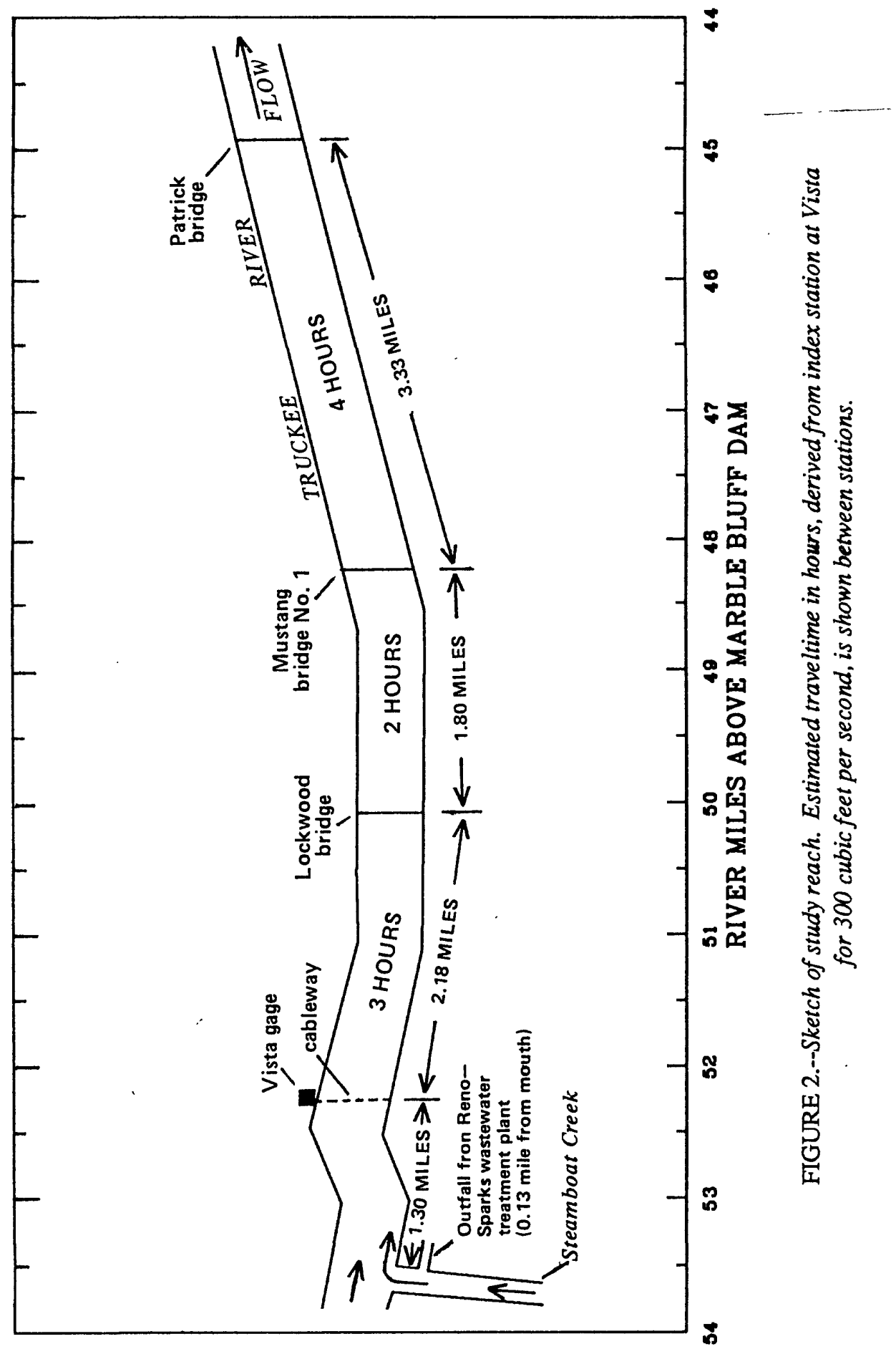




\section{SAMPLING METHODS AND ANALYSES}

Measurements of instantaneous streamflow were made about every 3 hours over the 25 -hour study period by using standard U.S. Geological Survey methods. With the exception of the Vista gage, streamflow measurements were by wading; at Vista, the measurements were made from the existing cableway. Engineers from the Reno-Sparks wastewater treatment plant were unable to provide effluent-discharge data during the study because equipment malfunction caused a loss of the record of flow (Thomas Swan, City of Reno, oral communication, 1985).

Traveltime of water from one station to the next downstream station was estimated by using equations for the index station at Vista. The equations were derived from U.S. Geological Survey time-of-travel studies in 1979-80 using dye-tracing techniques (Brown and others, 1986).

Water samples for chemical analysis were collected every 2 hours with a DH-48 depth-integrating suspended sediment sampler (Guy and Norman, 1970), using the equal-discharge-increment method (U.S. Geological Survey, 1977, chapters 3-26). The samples were collected at the predetermined centroids across the stream and were subsequently composited, mixed, and split into subsamples for the determination of total phosphorus and total arsenic. Subsamples for the determination of dissolved constituents (phosphorus, chloride, sulfate, and arsenic) were pumped from the compositor and filtered onsite through a pre-rinsed membrane filter of $0.45-\mu \mathrm{m}$ (micrometer) average pore-size diameter. The phosphorus samples were preserved with mercuric chloride and maintained in the dark at $4{ }^{\circ} \mathrm{C}$ or less until analyzed at the laboratory. Arsenic was preserved with concentrated nitric acid. Phosphorus in the filtrate and in the whole-water sample was measured at the Geological Survey Central Laboratory, Arvada, Colo., by using the acidpersulfate digestion method (Skougstad and others, 1979, p. 453, 491) following an extraction procedure for low-level analysis (Strickland and Parsons, 1968, p. 53).

Dissolved chloride, sulfate, and arsenic concentrations were also determined at the Geological Survey laboratory according to the methods described by Skougstad and others (1979).

Onsite measurements of specific conductance, water temperature, $\mathrm{pH}$, and dissolved oxygen were made with standard meters and probes that were calibrated about every 4 hours. Specific-conductance standards and $\mathrm{pH}$ buffers for each sampling station were prepared from single stock solutions.

Physical and chemical data collected during the present study are listed in table 6.

Chemical analyses of total phosphorus from the wastewater effluent were provided by Nevada Division of Environmental Protection staff. Effluent samples were collected by a portable sampler that was timed to automatically collect samples every 2 hours during the study. The samples were analyzed for total phosphorus at the Nevada State Health Laboratory, Reno, Nev., using the acid-persulfate digestion method. 


\section{WORKING HYPOTHESES REGARDING THE POSSIBLE CAUSE OF OBSERVED INCREASE IN PHOSPHORUS CONCENTRATIONS}

On the basis of known geologic and hydrologic characteristics of the study area, seven hypotheses were developed regarding the possible source of or cause for the observed increase in phosphorus concentrations between Lockwood and Patrick:

1. Ground-water inflow from highly fractured volcanic rocks.

2. Leachate from domestic septic tanks.

3. Irrigation return flow and fertilizers.

4. Mobilization of phosphorus from local gravel-mining operations.

5. Mobilization of phosphorus from river-bottom sediments.

6. Time-of-travel phenomenon (fixed-station, fixed-time monitoring of high phosphorus concentrations from the Reno-Sparks wastewater treatment plant).

7. Errors in analytical determinations or sampling procedures, or both.

Mobilization of phosphorus from river-bottom sediments (item 5 above) was an attractive hypothesis because an internal process could explain a measurable increase in phosphorus without an accompanying increase in some other commonly measured water-quality variable, such as dissolved solids. The difficulty with this idea, however, is that the calculated sediment-release rates required to produce the observed increases in concentration for three of the four U.S. Geological Survey synoptic-data sets (220 to 1,060 milligrams per day per square meter $\left[(\mathrm{mg} / \mathrm{day}) / \mathrm{m}^{2}\right]$ as $\left.\mathrm{P}\right\}$, were several orders of magnitude greater than that reported in the literature for either oxic or anoxic sediments [which range from 0.000023 to $154(\mathrm{mg} / \mathrm{day}) / \mathrm{m}^{2}$ as $\mathrm{P}$ (Nowlin, 1987, p. 186)].

Conceptually, the difficulty in accepting the thcory of a "real" input from an outside source, is that much of the available data frequently indicated no increase in other water-quality variables (dissolved solids, for example) that might reasonably be expected to accompany an accretion of phosphorus.

\section{STREAMFLOW CONDITIONS DURING DIEL STUDY}

The Truckee River is a highly regulated stream. The annual flow is largely controlled under the direction of a Federal Watermaster as specified by court decree (Brown and others, 1986, p. 29-37). A period of sustained low flow (less than $400 \mathrm{ft}^{3} / \mathrm{s}$ ) was forecast in the reach just downstream from the Reno-Sparks area for August 1984. Such a flow condition was desirable from the standpoint of study objectives for two reasons. First, an antecedent period of stable, low flow was needed to negate the possibility of accretion of phosphorus in the study reach due to return flow from bank storage associated with preceding high stages. Second, streamflow of 200 to $400 \mathrm{ft}^{3} / \mathrm{s}$ was needed to provide a proper comparison with previous analyses that showed an increase in phosphorus concentrations at Lockwood during such flow regimes.

Streamflow during the diel study period on August $15-16$ averaged about $300 \mathrm{ft}^{3} / \mathrm{s}$ at each measuring station (table 1). This followed a 12-day period with mean daily streamflow less than $400 \mathrm{ft}^{3} / \mathrm{s}$ as recorded at the Vista gage (Frisbie and others, 1985, p. 171). Thus, the desirable flow criteria that were believed necessary for adequate interpretation of water-quality data for this study appeared to be met. 
As shown in the graph of individual measurements (figure 3) and in the summary statistics (table 1), streamflow varied little with respect to location or time throughout the study period. Among the four stations, the Vista gage, because of access to the cableway, and Mustang, because of cross-section uniformity, were considered the better stations at which to make accurate streamflow measurements.

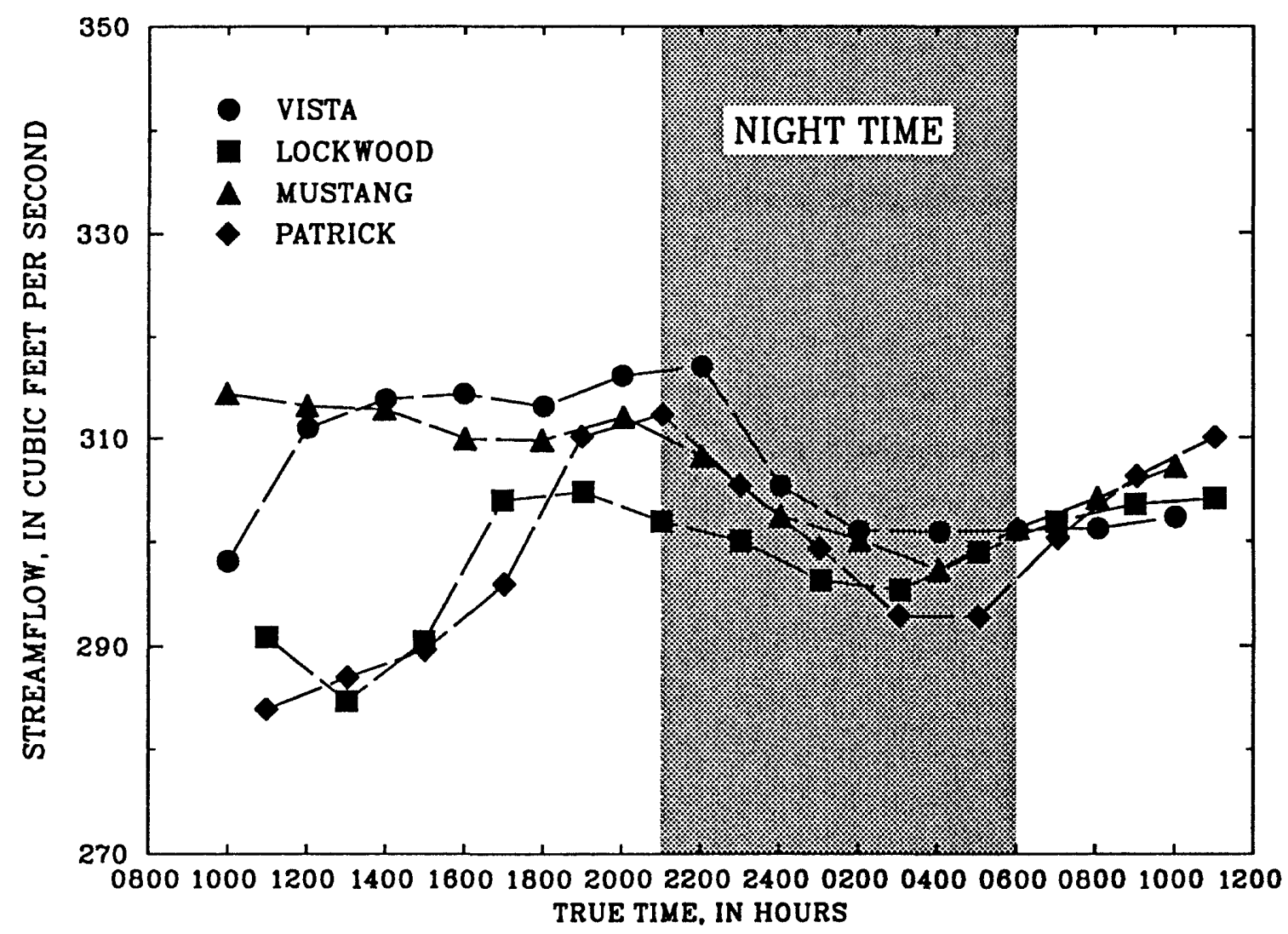

FIGURE 3.--Instantaneous streamflow of river during diel study of August 15-16, 1984.

The streamflow statistics contained in table 1 indicate a minimum probable error (one standard deviation) ranging from about 6 to $10 \mathrm{ft}^{3} / \mathrm{s}$ about the mean, depending on the station. A probable error of two standard deviations $\left(12-20 \mathrm{ft}^{3} / \mathrm{s}\right)$, however, is a more likely value of measurement uncertainty, on the basis of the hydrographer's subjective rating of each streamflow measurement.

For the purposes of this study, the streamflow from Vista to Patrick can thus be considered in a steady state during the study period, and because of measurement uncertainties, any inflow that totaled less than about $25 \mathrm{ft}^{3} / \mathrm{s}$ (as measured at Patrick) could not be detected with any degree of confidence. Thus, changes in observed loads greater than 10 percent between sampling stations probably could be attributed to changes in concentration of a constituent rather than changes in streamflow. 


\title{
WATER-QUALITY CHARACTERISTICS DURING DIEL STUDY
}

\author{
Conservative Water-Quality Variables and Arsenic
}

In most hydrologic systems, a measurable flux of phosphorus (or almost any constituent, for that matter) from an outside source will be accompanied by a measurable change in some independent "major" constituent or characteristic of the hydrologic system, such as the overall dissolved-solids concentration, a component of the dissolved solids, or the flow quantity. Such predictable occurrences give the hydrologist added confidence of understanding the system being investigated.

Because the inflow of phosphorus from natural ground-water systems, or from septic leachfields (phosphorus is a component of sewage), was a possible source of the apparent historical phosphorus increase between Lockwood and Patrick, certain companion variables were monitored during the present study: Chloride, sulfate, dissolved solids (on the basis of specific conductance), and arsenic were selected for analyses in addition to phosphorus because of the generally known relation between these "tracer" constituents and ground water contaminated by sewage-disposal systems (Canter and Knox, 1986).

Other possible sources of phosphorus input were ruled out. An atmospheric input was entirely unreasonable considering the magnitude of the modeled estimates; an undiscovered surface inflow also seemed unlikely because the river reach had been walked, floated, and flown by many astute observers of such natural features.

The statistical data in table 1 show no significant changes in chloride, sulfate, or specific conductance within or between stations that could be attributed to anything other than random variability. Rigorous statistical measures, such as analysis of variance, proved to be a fruitless endeavor because the sample populations (raw data) of each of the aforementioned variables are nearly identical to the mean. In addition, no important differcnce existed in either the chloride load or sulfate load (table 2) between Vista and Patrick; the dissolvedsolids load, however, actually appeared to decrease (about 3 percent) between these two stations.

Thus, because of the invariability in time and space of measured chemical variables considered to be conservative in nature, and because of the stable streamflow conditions, no major input of phosphorus to the Truckee River between Vista and Patrick during this study is suggested.

Arsenic was selected for analysis because of its possible geochemical relation with phosphorus (Ferguson and Gavis, 1972, p. 1265). Occasional high concentrations of arsenic in the river have been attributed to geothermal sources tributary to Steamboat Creek, which in turn enters the river just upstream from Vista (Pacific Environmental Laboratory, 1979). An examination of the summary statistics in table 1 and loads in table 2 shows that arsenic, too, varied insignificantly both within and between stations over the 25-hour period. 
TABLE 1.--Summary statistics of water-quality data and streamflow for diel study of August 15-16, 1984

[Abbreviations: $\mathrm{ft}^{3} / \mathrm{s}$, cubic feet per second; mg/L, milligrams per liter; $N$, number of analyses; ${ }^{\circ} \mathrm{C}$, degrees Celsius; $\mu \mathrm{g} / \mathrm{L}$, micrograms per liter; $\mu \mathrm{s} / \mathrm{cm}$, microsiemens per centimeter at $25^{\circ} \mathrm{C}$

\begin{tabular}{|c|c|c|c|c|c|c|c|c|}
\hline $\begin{array}{l}\text { Constituent } \\
\text { or property, } \\
\text { and station }\end{array}$ & $\mathbf{N}$ & Maximum & $\operatorname{Mean}^{1}$ & Median & Minimum & $\begin{array}{l}\text { standard } \\
\text { deviation }\end{array}$ & $\begin{array}{l}\text { Standard } \\
\text { error of } \\
\text { mean }\end{array}$ & $\begin{array}{c}\text { Estimated } \\
\text { measurement } \\
\text { error }\end{array}$ \\
\hline \multicolumn{9}{|c|}{ Total phesphorus $(\mathrm{mo} / \mathrm{L})$} \\
\hline $\begin{array}{l}\text { Vista } \\
\text { Lockwood } \\
\text { Mustang } \\
\text { Patrick }\end{array}$ & $\begin{array}{l}13 \\
13 \\
13 \\
13\end{array}$ & $\begin{array}{r}0.188 \\
.172 \\
.156 \\
.153\end{array}$ & $\begin{array}{r}0.142 \\
.132 \\
.127 \\
.126\end{array}$ & $\begin{array}{r}0.135 \\
.127 \\
.129 \\
.120\end{array}$ & $\begin{array}{l}0.111 \\
.102 \\
.103 \\
.109\end{array}$ & $\begin{array}{l}0.027 \\
.024 \\
.020 \\
.016\end{array}$ & $\begin{array}{l}0.007 \\
.007 \\
.006 \\
.004\end{array}$ & $\begin{array}{l}0.005 \\
.005 \\
.005 \\
.005\end{array}$ \\
\hline \multicolumn{9}{|c|}{ Dissolved phosphorus $(\mathrm{mg} / I)$} \\
\hline $\begin{array}{l}\text { Vista } \\
\text { Lockwood } \\
\text { Mustang } \\
\text { Patrick }\end{array}$ & $\begin{array}{l}13 \\
13 \\
13 \\
13\end{array}$ & $\begin{array}{r}0.074 \\
.085 \\
.088 \\
.095\end{array}$ & $\begin{array}{r}0.059 \\
.069 \\
.073 \\
.080\end{array}$ & $\begin{array}{r}0.058 \\
.067 \\
.075 \\
.079\end{array}$ & $\begin{array}{l}0.048 \\
.067 \\
.061 \\
.067\end{array}$ & $\begin{array}{r}0.009 \\
.009 \\
.009 \\
.008\end{array}$ & $\begin{array}{l}0.002 \\
.002 \\
.002 \\
.002\end{array}$ & $\begin{array}{l}0.005 \\
.005 \\
.005 \\
.005\end{array}$ \\
\hline \multicolumn{9}{|c|}{ Dissolyed chleride $(\mathrm{mg} / \mathrm{L})$} \\
\hline $\begin{array}{l}\text { Vista } \\
\text { Lockwood } \\
\text { Mustang } \\
\text { Patrick }\end{array}$ & $\begin{array}{l}13 \\
13 \\
13 \\
13\end{array}$ & $\begin{array}{l}14 \\
14 \\
14 \\
14\end{array}$ & $\begin{array}{l}12 \\
13 \\
12 \\
13\end{array}$ & $\begin{array}{l}12 \\
13 \\
12 \\
13\end{array}$ & $\begin{array}{l}11 \\
11 \\
11 \\
12\end{array}$ & $\begin{array}{l}1.1 \\
.87 \\
1.0 \\
.64\end{array}$ & $\begin{array}{r}0.31 \\
.24 \\
.29 \\
.18\end{array}$ & $\begin{array}{l}1 \\
1 \\
1 \\
1\end{array}$ \\
\hline \multicolumn{9}{|c|}{ Dissolved sulfate $(\mathrm{mg} / \mathrm{L})$} \\
\hline $\begin{array}{l}\text { Vista } \\
\text { Lockwood } \\
\text { Mustang } \\
\text { Patrick }\end{array}$ & $\begin{array}{l}13 \\
13 \\
13 \\
13\end{array}$ & $\begin{array}{l}23 \\
23 \\
24 \\
24\end{array}$ & $\begin{array}{l}22 \\
22 \\
22 \\
23\end{array}$ & $\begin{array}{l}22 \\
22 \\
22 \\
23\end{array}$ & $\begin{array}{l}21 \\
21 \\
20 \\
21\end{array}$ & $\begin{array}{l}0.72 \\
.63 \\
1.3 \\
1.0\end{array}$ & $\begin{array}{r}0.20 \\
.17 \\
.36 \\
.27\end{array}$ & $\begin{array}{l}3 \\
3 \\
3 \\
3\end{array}$ \\
\hline \multicolumn{9}{|c|}{ Dissolved arsenic $(\mu \mathrm{g} / L)$} \\
\hline $\begin{array}{l}\text { Vista } \\
\text { Lockwood } \\
\text { Mustang } \\
\text { Patrick }\end{array}$ & $\begin{array}{l}13 \\
13 \\
13 \\
13\end{array}$ & $\begin{array}{l}11 \\
12 \\
12 \\
12\end{array}$ & $\begin{array}{r}9 \\
10 \\
10 \\
10\end{array}$ & $\begin{array}{l}10 \\
11 \\
10 \\
11\end{array}$ & $\begin{array}{l}7 \\
7 \\
8 \\
9\end{array}$ & $\begin{array}{r}1.5 \\
1.5 \\
1.1 \\
.9\end{array}$ & $\begin{array}{r}0.41 \\
.43 \\
.30 \\
.24\end{array}$ & $\begin{array}{l}3 \\
3 \\
3 \\
3\end{array}$ \\
\hline \multicolumn{9}{|c|}{ Specific conductance $(\mu \mathrm{S} / \mathrm{cm})$} \\
\hline $\begin{array}{l}\text { Vista } \\
\text { Lockwood } \\
\text { Mustang } \\
\text { Patrick }\end{array}$ & $\begin{array}{l}13 \\
13 \\
13 \\
13\end{array}$ & $\begin{array}{l}310 \\
310 \\
300 \\
300\end{array}$ & $\begin{array}{l}284 \\
295 \\
285 \\
286\end{array}$ & $\begin{array}{l}280 \\
290 \\
290 \\
283\end{array}$ & $\begin{array}{l}265 \\
275 \\
262 \\
280\end{array}$ & $\begin{array}{r}13 \\
12 \\
13 \\
7.2\end{array}$ & $\begin{array}{l}3.5 \\
3.4 \\
3.5 \\
2.0\end{array}$ & $\begin{array}{l}9 \\
9 \\
9 \\
9\end{array}$ \\
\hline \multicolumn{9}{|c|}{ Temperature $\left({ }^{\circ} \mathrm{C}\right)$} \\
\hline $\begin{array}{l}\text { Vista } \\
\text { Lockwood } \\
\text { Mustang } \\
\text { Patrick }\end{array}$ & $\begin{array}{l}13 \\
13 \\
13 \\
13\end{array}$ & $\begin{array}{l}22.0 \\
21.0 \\
22.0 \\
22.0\end{array}$ & $\begin{array}{l}20.5 \\
20.0 \\
20.5 \\
20.0\end{array}$ & $\begin{array}{l}20.5 \\
21.0 \\
20.5 \\
20.0\end{array}$ & $\begin{array}{l}18.0 \\
18.0 \\
19.0 \\
19.0\end{array}$ & $\begin{array}{l}1.3 \\
1.2 \\
1.0 \\
1.2\end{array}$ & $\begin{array}{r}0.36 \\
.33 \\
.28 \\
.33\end{array}$ & $\begin{array}{r}0.5 \\
.5 \\
.5 \\
.5\end{array}$ \\
\hline $\mathrm{pH}$ (units) & & & & & & & & \\
\hline $\begin{array}{l}\text { Vista } \\
\text { Lockwood } \\
\text { Mustang } \\
\text { Patrick }\end{array}$ & $\begin{array}{l}13 \\
13 \\
13 \\
13\end{array}$ & $\begin{array}{l}8.2 \\
8.2 \\
8.1 \\
8.1\end{array}$ & $\begin{array}{l}7.8 \\
8.0 \\
8.0 \\
7.8\end{array}$ & $\begin{array}{l}7.8 \\
8.0 \\
7.9 \\
7.8\end{array}$ & $\begin{array}{l}7.0 \\
7.7 \\
7.9 \\
7.6\end{array}$ & $\begin{array}{r}0.27 \\
.14 \\
.10 \\
.16\end{array}$ & $\begin{array}{r}0.08 \\
.04 \\
.02 \\
.05\end{array}$ & $\begin{array}{r}0.1 \\
.1 \\
.1 \\
.1\end{array}$ \\
\hline \multicolumn{9}{|c|}{ Dissolved oxygen (ma/L) } \\
\hline $\begin{array}{l}\text { Vista } \\
\text { Lockwood } \\
\text { Mustang } \\
\text { Patrick }\end{array}$ & $\begin{array}{l}13 \\
13 \\
13 \\
12\end{array}$ & $\begin{array}{r}8.5 \\
7.6 \\
7.5 \\
7.5\end{array}$ & $\begin{array}{l}6.5 \\
6.8 \\
6.5 \\
6.4\end{array}$ & $\begin{array}{l}5.9 \\
6.9 \\
6.4 \\
6.0\end{array}$ & $\begin{array}{l}5.3 \\
6.0 \\
5.6 \\
5.3\end{array}$ & $\begin{array}{l}1.2 \\
.61 \\
.79 \\
.83\end{array}$ & $\begin{array}{r}0.34 \\
.71 \\
.22 \\
.24\end{array}$ & $\begin{array}{r}0.3 \\
.3 \\
.3 \\
.3\end{array}$ \\
\hline \multicolumn{9}{|c|}{ Streamflow $\left(f t^{3}(s)\right.$} \\
\hline $\begin{array}{l}\text { Vista } \\
\text { Lockwood } \\
\text { Mustang } \\
\text { Patrick }\end{array}$ & $\begin{array}{l}13 \\
13 \\
13 \\
13\end{array}$ & $\begin{array}{l}317 \\
305 \\
314 \\
312\end{array}$ & $\begin{array}{l}307 \\
298 \\
307 \\
299\end{array}$ & $\begin{array}{l}305 \\
300 \\
308 \\
299\end{array}$ & $\begin{array}{l}298 \\
285 \\
297 \\
284\end{array}$ & $\begin{array}{l}7.0 \\
6.3 \\
5.6 \\
9.2\end{array}$ & $\begin{array}{l}1.9 \\
1.7 \\
1.6 \\
2.6\end{array}$ & $\begin{array}{l}20 \\
20 \\
20 \\
25\end{array}$ \\
\hline
\end{tabular}

1 Arithmetic mean, except for $\mathrm{pH}$, which is logarithmic.

2 Sources of estimated errors: Skougstad and others (1979) for phosphorus chloride, sulfate, and arsenic; manufacturer's statement of measurement error for respective electronic read-out device for specific conductance, temperature, pH, and dissolved oxygen; hydrographer's qualitative assessment of measuring conditions for streamflow. (Note: Except for streamflow, measurement error does not include error associated with sampling.) 


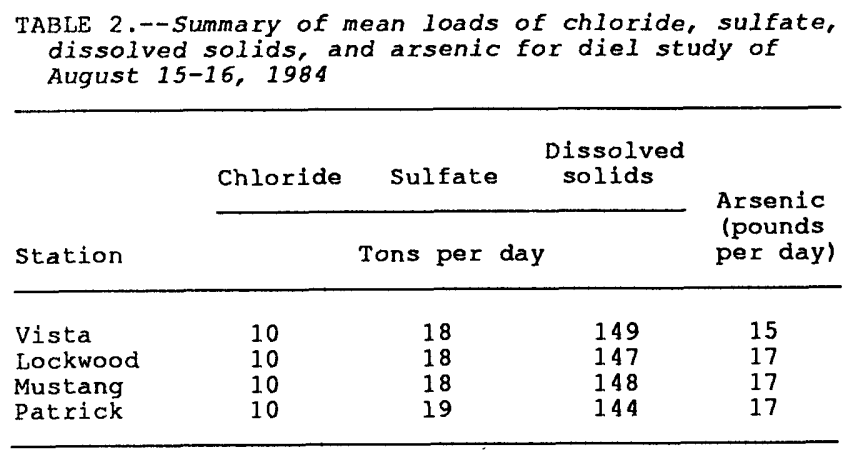

\section{Phosphorus}

Total phosphorus (TP) clearly shows a distinct cyclic variation in concentration over the diel period (figure 4A). The TP data in figure 4A were plotted against true sampling time at each station. Each curve in the graph shows a fairly wide difference between high and low values. Minimum concentrations occurred at all stations early in the sampling period, between 1400 and 2200 hours on August 15 (that is, during an overall time span of about 8 hours), and the minima were somewhat sequentially offset with time in an overall downstream direction. Maximum concentrations of TP occurred at all stations late in the sampling period, between midnight and midmorning ( 0900 hours) on the following day, an overall time span of 9 hours. Note in figure 4A that peak concentrations are clearly offset sequentially with time in the downstream direction. Also note the "crossing over" of the curves beginning at 0700 hours on the second day. On the basis of the plots in figure 4A alone, TP clearly appears to increase from Lockwood to Patrick during the morning. In particular, a water-quality monitoring program having a sampling protocol in the time period from about 1000 hours to 1200 hours would provide data indicating higher concentrations at both Mustang and Patrick than at Lockwood.

Dissolved phosphorus (DP), too, showed a discernible cyclic pattern over time (figure 5A). Minimum concentrations occurred between 1400 hours and 2300 hours (spanning about 9 hours), and maximum concentrations occurred at and after midnight, in a successively downstream direction. As with TP (figure 4A), a plot of DP concentration as related to true sampling time (figure 5A) shows an apparent "crossing over" of curves.

Such a reversal in concentration occurring at a particular time between some stations can be explained by evaluating the river's time-of-travel characteristics. As previously mentioned, time-of-travel was hypothesized as a possible cause for the observed increase in phosphorus in previous data from Lockwood to Patrick. This hypothesis is examined using the data collected during the August 15-16,1984, diel study. Traveltimes estimated using a flow value of $300 \mathrm{ft}^{3} / \mathrm{s}$ from the index station at Vista are: Vista to Lockwood, 3 hours; Lockwood to Mustang, 2 hours; and Mustang to Patrick, 4 hours; thus, total traveltime from Vista to Patrick would be about 9 hours (table 3). These estimated times were then used to shift each sample-collection time for Lockwood, Mustang, and Patrick by 3, 5, and 9 hours, respectively. (Sample-collection times at the Vista index station were not adjusted in this manner.) 


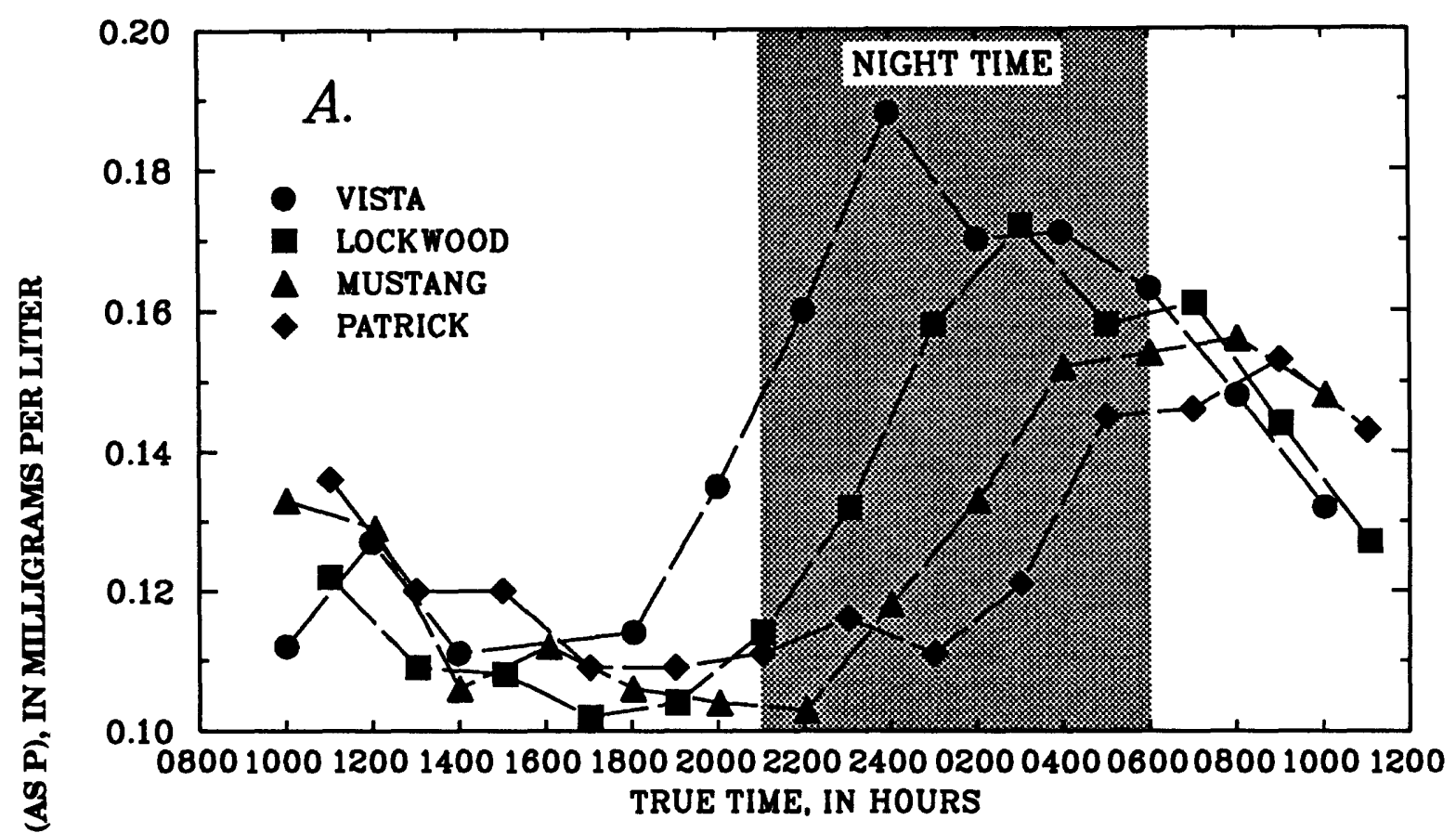

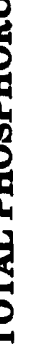

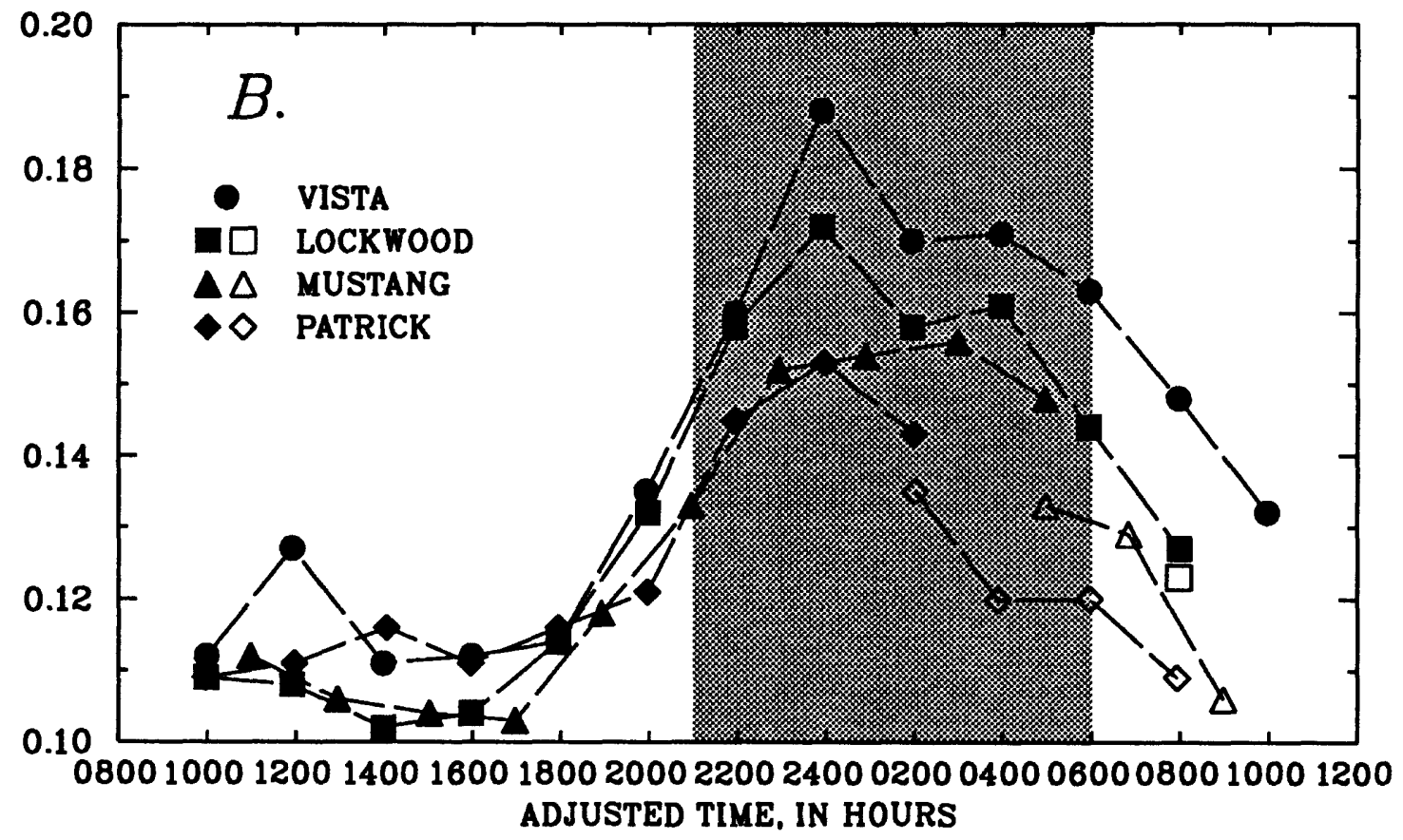

FIGURE 4.--Total-phosphorus concentration in river during the diel study of August 15-16, 1984. A. True sampling time. B. True sampling time adjusted for traveltime. In part B, open symbols denote data points that have been moved from the beginning of the data sets to the end. See text for discussion of adjustments. 

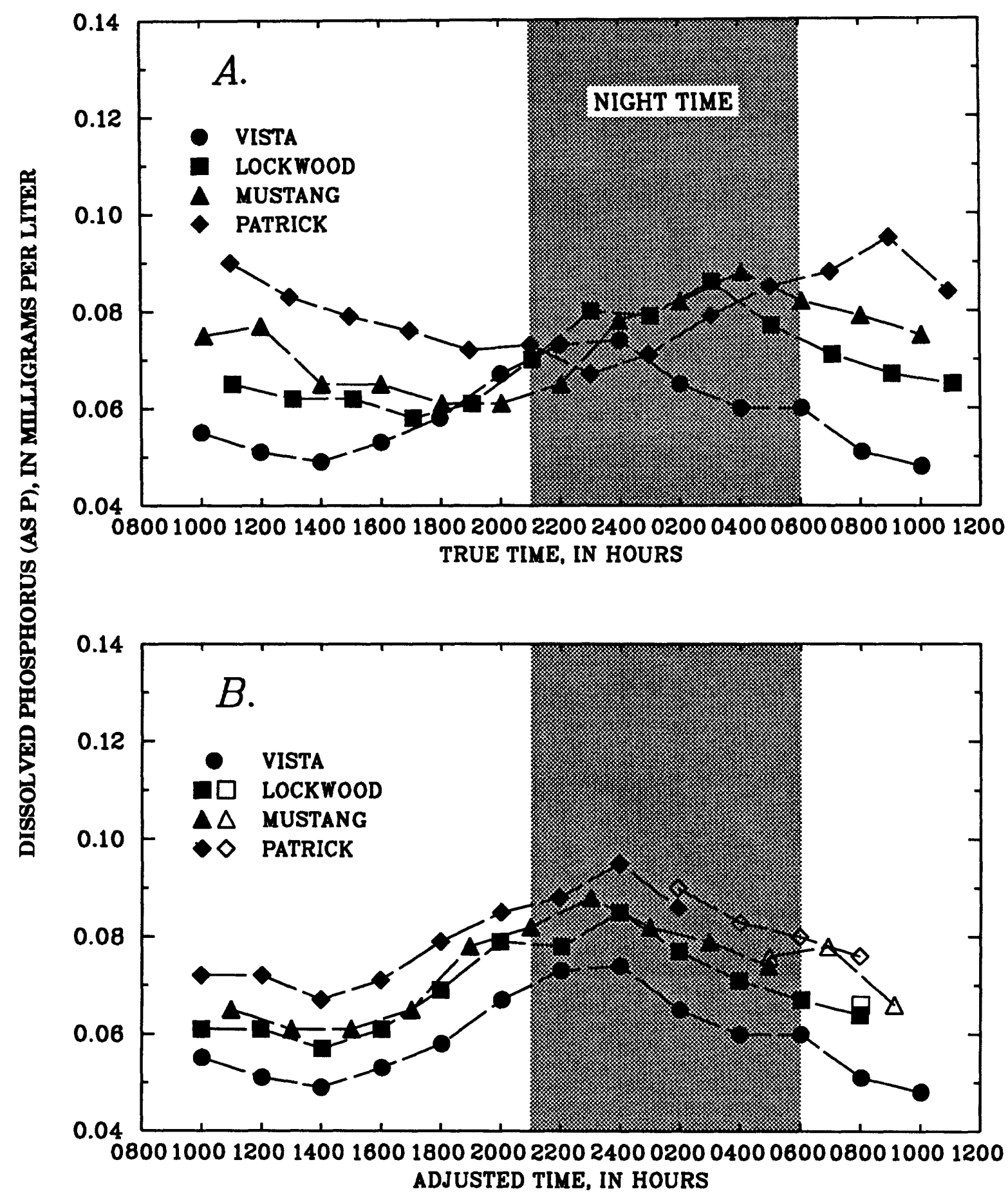

FIGURE 5.--Dissolved-phosphorus concentration in river during the diel study of August 15-16, 1984.

A. True sampling time. B. True sampling time adjusted for traveltime. In part $\mathrm{B}$, open symbols denote data points that have been moved from the beginning of the data sets to the end. See text for discussion of adjustments. 
TABLE 3.--Summary of physical conditions at four sampling stations during diel study of August 15-16, 1984

\begin{tabular}{|c|c|c|c|c|c|c|c|}
\hline \multirow[b]{2}{*}{ Station } & \multirow[b]{2}{*}{$\begin{array}{l}\text { Mean flow } \\
\text { (cubic feet } \\
\text { per second) }\end{array}$} & \multirow[b]{2}{*}{$\begin{array}{l}\text { Mean } \\
\text { depth } \\
\text { (feet) }\end{array}$} & \multirow[b]{2}{*}{$\begin{array}{l}\text { Mean } \\
\text { velocity } \\
\text { (feet per } \\
\text { second) }\end{array}$} & \multirow[b]{2}{*}{$\begin{array}{l}\text { Width } \\
\text { (feet) }\end{array}$} & \multirow[b]{2}{*}{$\begin{array}{l}\text { River- } \\
\text { bottom } \\
\text { material }\end{array}$} & \multicolumn{2}{|c|}{$\begin{array}{c}\text { Traveltime } \\
\text { between stations }\end{array}$} \\
\hline & & & & & & Hours & $\begin{array}{c}\text { Cumulative } \\
\text { hours from } \\
\text { Vista }\end{array}$ \\
\hline Vista & 307 & 2.5 & 1.2 & 104 & $\begin{array}{l}\text { Sand, } \\
\text { silt }\end{array}$ & -- & -- \\
\hline Lockwood & 298 & 1.6 & 1.9 & 99 & $\begin{array}{l}\text { Cobbles, } \\
\text { algaee }\end{array}$ & 3 & 3 \\
\hline Mustang & 307 & 1.7 & 2.0 & 89 & do. & 2 & 5 \\
\hline Patrick & 299 & 2.5 & 1.4 & 87 & do. & 4 & 9 \\
\hline
\end{tabular}

Beginning with Patrick, the most downstream station, the true sampling time for each data-collection event was adjusted by the appropriate traveltime with respect to Vista. Thus, the recorded peak TP concentration at Patrick $(0.153 \mathrm{mg} / \mathrm{L})$, at 0900 hours on August 16 in figure $4 \mathrm{~A}$, is shifted 9 hours to the left in reference to Vista; the result of this shift is shown in figure 4B. In theory, this adjusted concentration represents the "Vista concentration" after traversing the subreaches to Patrick.

When the true sampling times at the three downstream sites are shifted to account for traveltime from Vista, the adjusted times for first samples at the three sites precede the true time of the first sample at Vista by as much as 8 hours. To enhance the clarity of relations shown in figure $4 \mathrm{~B}$, all shifted data points that would precede the first Vista data point as a result of the shift, have been moved from the beginning of the data set to the end. For example, the first four data points at Patrick (1100-1700 hours on August 15; see figure 4A) would be shifted 9 hours to the left (to 0200-0800 hours on August 15) as a result of the traveltime adjustment. In figure $4 \mathrm{~B}$, however, these data points are shown by open symbols at the end of the shifted Patrick data set (at 0200-0800 hours on August 16) rather than by solid symbols at the beginning of the set.

The adjustments described above for total phosphorus (figure 4) also are used for dissolved and suspended phosphorus (figures 5 and 6, respectively).

Graphs of TP and DP, corrected for traveltime (figures 4B and 5B, respectively), reveal the following: (1) the time-of-travel estimates appear to be reasonably good for the study reach at a streamflow of about $300 \mathrm{ft}^{3} / \mathrm{s}$-- that is, the peaks and valleys of the curves match quite well; (2) the pattern of phosphorus distribution along the reach becomes much clearer in light of traveltime adjustment--the "crossing over" of curves has been virtually eliminated; and (3) the average concentration of a nonconscrvative constituent such as dissolved phosphorus, an essential nutrient for plant growth and subject to diel fluctuations, has limited value when forming a conceptual or numerical model to understand dynamic processes in natural aquatic systems. 
Considering the sampling time of 1000 hours, the apparent increase in concentration of TP between Lockwood and Patrick (figure 4A) is not evident in the curves that are adjusted for time of travel (figure 4B). The focus on sampling at about 1000 hours in this discussion is not frivolous. The Desert Research Institute habitually sampled from about 1000 to 1200 hours at Vista and Tracy (figure 1, table 5). Tracy is 4.3 river miles, or about 5 hours traveltime (at $300 \mathrm{ft}^{3} / \mathrm{s}$ ), downstream from Patrick; and the instream mechanisms that affect the concentration of phosphorus at Patrick are also valid for Tracy. Theoretically, a water sample that is "grabbed" at Vista from the river bank opposite a major point source a short distance upstream might indicate a lower concentration relative to a well-mixed downstream station (such as Tracy), given the brief driving and sampling time (about 30-40 minutes) between Vista and Tracy (table 5).

Concentrations of dissolved phosphorus that are adjusted for traveltime (figure 5B) suggest a fairly uniform trend of increasing concentrations in the downstream direction. A comparison of the plots of unadjusted and adjusted time (figures 5A and 5B) clarifies a possible misinterpretation of "lower" concentrations of DP at Patrick compared with Lockwood, if one were to habitually sample without considering the consequences of traveltime. This consideration becomes especially important in streams receiving a substantial point-source input of material--such as from sewage outfalls--that may have its own man-caused diel cycle, which is then superimposed on the stream's natural 24-hour rhythm.

Because DP is a component of TP, an examination of the suspended, or particulate fraction (the calculated difference between analytically determined TP and DP) is useful to help explain the apparent increase in phosphorus as suggested by previous data. Graphs of suspended phosphorus, unadjusted for traveltime (figure 6A) and adjusted for traveltime (figure 6B), indicate that concentrations generally decrease between Vista and Patrick. The differences increase with increasing concentrations of particulate phosphorus during nighttime hours, with a maximum loss of about $0.05 \mathrm{mg} / \mathrm{L}$ (adjusted for traveltime) during the night.

Hence, the data collected during the present study suggest that only the dissolved-phosphorus fraction increased in a downstream direction (table 1, figures 5A and 5B). The increase in DP from Lockwood to Patrick was about $0.01 \mathrm{mg} / \mathrm{L}$, which is about one standard deviation of the mean (table 1).

Assuming that the downstream increase in DP concentration is real, then a source or process must account for this occurrence. The most likely source of an increase in DP from Vista to Patrick is from within the river system rather than from without, because (1) no increase in the particulate fraction indicating a point source was observed, and (2) a ground-water source, although possible, is unlikely because no measurable increases in other attendant hydrologic variables such as specific conductance, chloride, sulfate, or arsenic were observed.

A more likely explanation for an observed downstream increase in DP is that, overall, the rate of dissolution of particulate phosphorus by a variety of biochemical activities in the river slightly exceeds the rate of uptake of DP by the aquatic plants. That such a mechanism is at work in the reach from Vista to Patrick is suggested both by the bar graph of mean concentrations of dissolved and particulate phosphorus (figure 7), and by the load of phosphorus (table 4) at each sampling site. The data indicate that DP increases downstream with an attendant decrease in the suspended, or particulate, fraction. Thus, a substantial conversion from one form of phosphorus to another in the water column is possible without an accompanying change in the total phosphorus concentration. The importance of partitioning of phosphorus between the suspended and dissolved phases has been documented by others (Keup, 1968; Stumm and Leckie, 1971; Dorich and others, 1980; Froelich, 1988). 

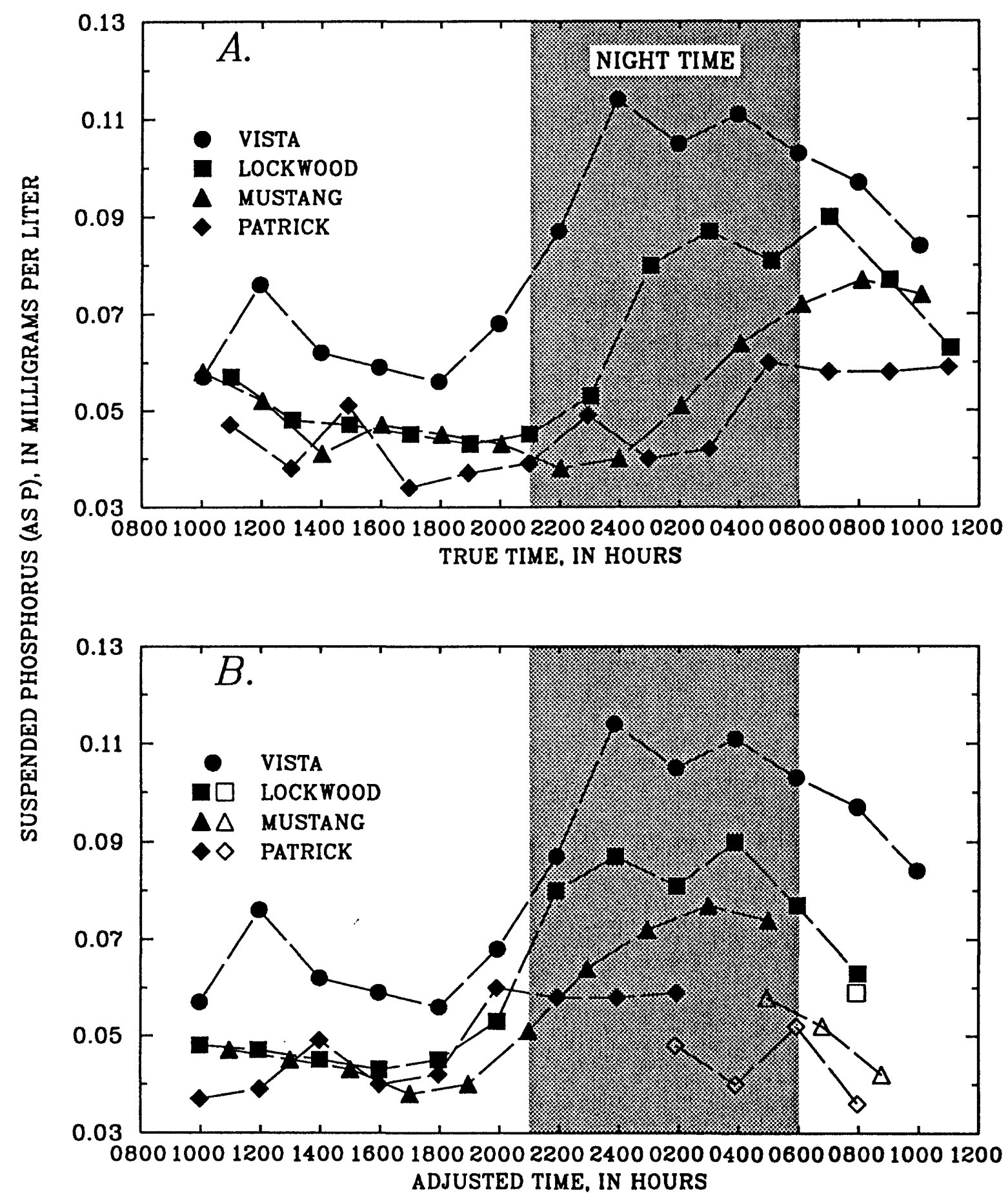

FIGURE 6.--Suspended-phosphorus concentration in river during the diel study of August 15-16, 1984. A. True sampling time. B. True sampling time adjusted for traveltime. In part B, open symbols denote data points that have been moved from the beginning of the data sets to the end. See text for discussion of adjustments. 
TABLE 4.--Summary of mean phosphorus loads (rounded) for diel study of August 15-16, 1984

\begin{tabular}{llcc}
\hline & \multicolumn{2}{c}{ Phosphorus (pounds per day) } \\
\cline { 2 - 4 } & Total & Dissolved & Suspended \\
Station & & & \\
\hline Vista & 240 & 100 & 140 \\
Lockwood & 210 & 110 & 100 \\
Mustang & 210 & 120 & 90 \\
Patrick & 200 & 130 & 70 \\
\hline
\end{tabular}

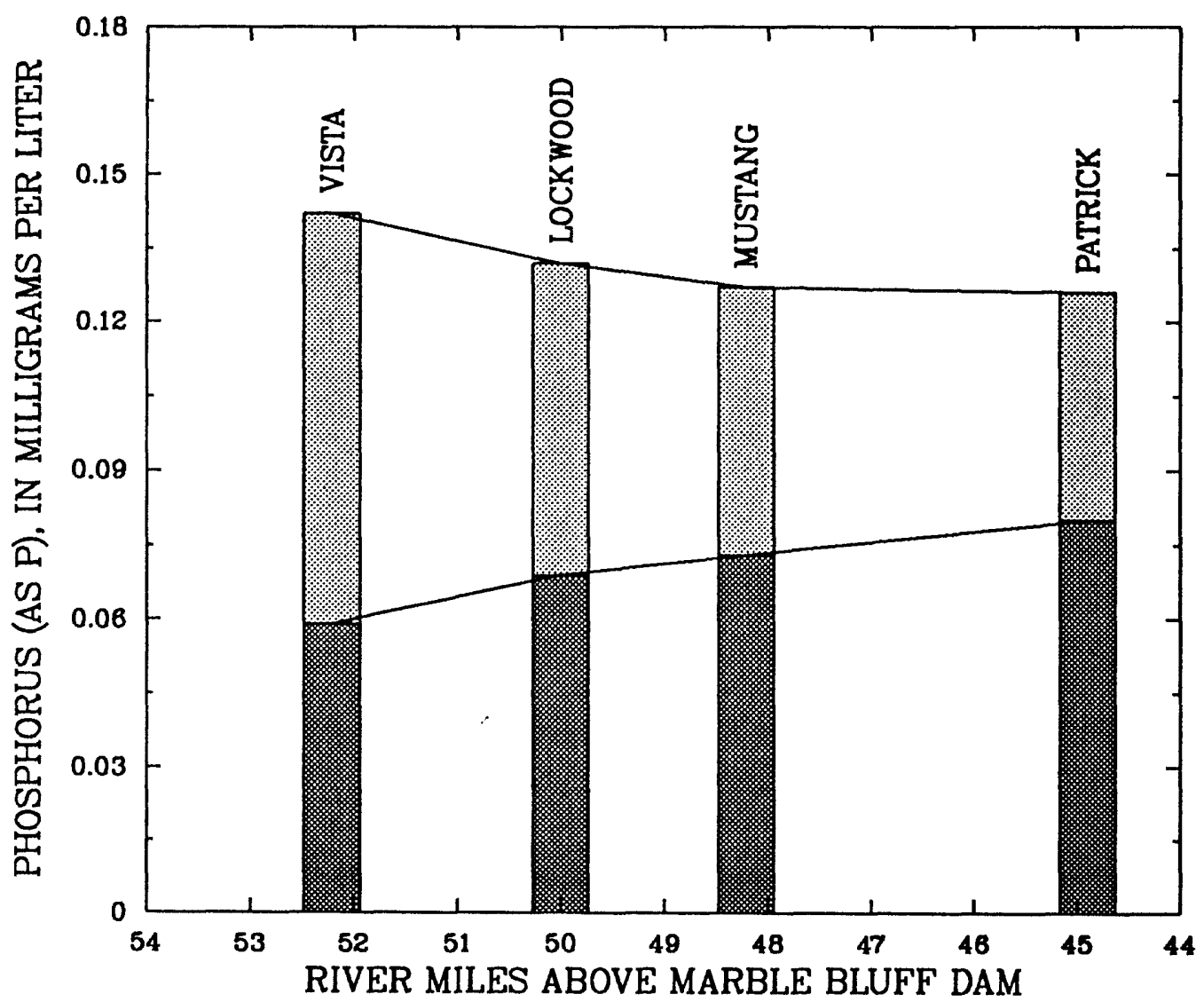

EXPLANATION

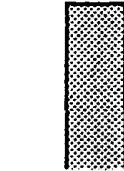

SUSPENDED PHOSPHORUS

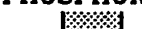

FIGURE 7.--Mean concentrations of total, dissolved, and suspended phosphorus in river during the diel study of August 15-16, 1984. Each bar represents 13 samples. 
The dicl phosphorus cycle at each station is greally influenced by the daily operation of the cities' wastewater-treatment plant, the outfall from which impacts the Truckee River just upstream from the Vista station (figure 2). This is important from the standpoint of understanding the variability of phosphorus in the river as it relates to the timing and the method of collecting water samples.

An examination of the graph of total phosphorus in the treated sewage effluent during the present diel sampling period (figure 8) suggests that maximum concentrations are entering the river at night, when the potential for nutrient uptake by aquatic plants is at a minimum. In this connection, the graphs of dissolved oxygen (figures 9 and 10) show that the total metabolic activity of aquatic plants is decreased during the night when photosynthesis is shut off. Hypothetically, a nighttime effluent which contained maximum concentrations of phosphorus, might not be available to the river's biota until some distance downstream, depending on streamflow. For example, given a traveltime of 11 hours (at $300 \mathrm{ft}^{3} / \mathrm{s}$ ) from the sewage outfall to Patrick, the TP concentration in effluent at 8 p.m. (2000 hours) would arrive at Patrick the following morning at 7 a.m. (0700 hours), near the start of the photosynthetic period for that day (figures 9 and 10). In other words, a "parcel" of phosphorus-rich water from the wastewater-treatment plant could conceivably pass through the reach from Vista to Patrick during the night without the concentration being substantially affected by the aquatic plants.

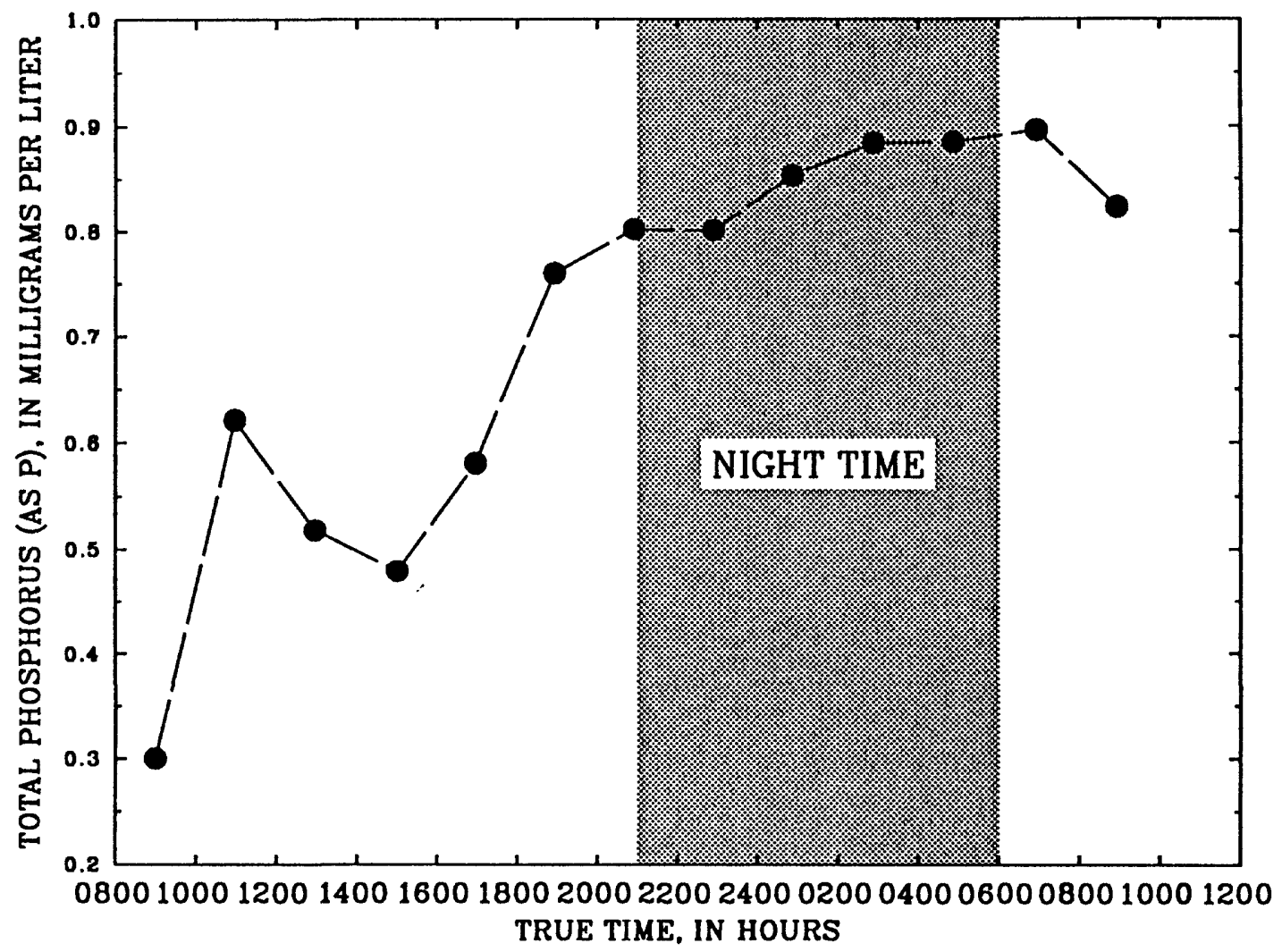

FIGURE 8.--Total-phosphorus concentration in effluent from the Reno-Sparks Wastewater Treatment Plant during the diel study of August 15-16, 1984 (true sampling time). Note: Corresponding effluent discharge data from the treatment plant were unavailable to the author because of equipment malfunction in the plant. 
As mentioned earlier, effluent flow data during the present sampling period were not available; thus, corresponding phosphorus loads could not be calculated. But, using the U.S. Geological Survey synoptic data set for August 1980 (La Camera and others, 1985, p. 38-39) to plot the effluent load of dissolved phosphorus (figure 11), reveals the following: (1) The maximum measured load was 3-fold greater than the minimum, (2) the peak load was near midnight, and, (3) the phosphorus loads from the wastewater treatment plant were frequently highest during the night (from 2100 to 0600 hours). The August 1980 data set, albeit 4 years earlier, indicates the probable 24-hour variability of phosphorus that was discharged to the Truckee River from the Reno-Sparks wastewater treatment plant from 1977 through at least 1984. (A similar pattern of high nighttime effluent loads is indicated by the U.S. Geological Survey synoptic data set for August 1979; La Camera and others, 1985, p. 38-39.)

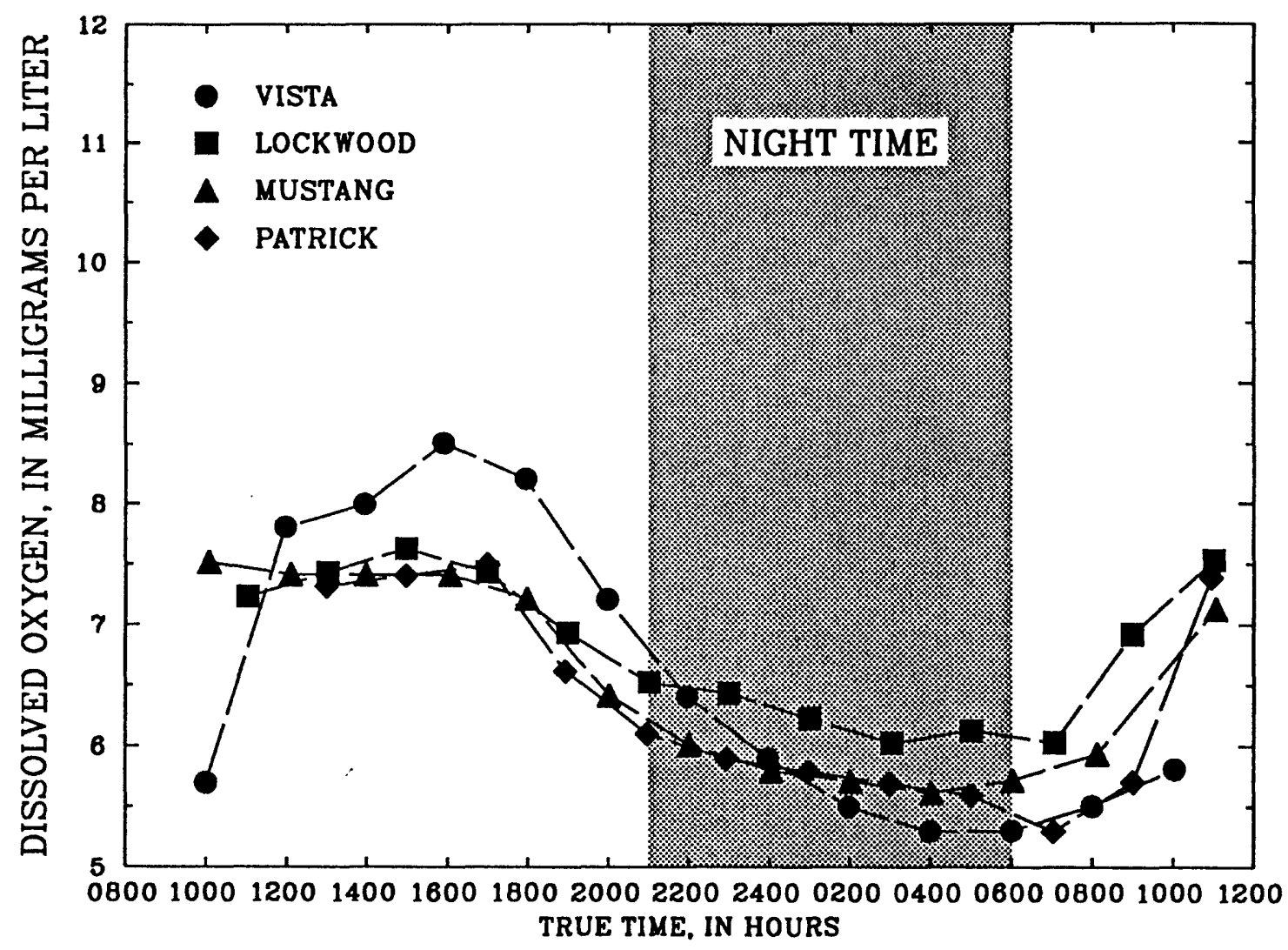

FIGURE 9.--Dissolved-oxygen concentration in river during the diel study of August 15-16, 1984 (true sampling time). 
To summarize, during the August 15-16 diel sampling period, TP concentration was observed to decrease in a downstream direction (11 percent mean loss from Vista to Patrick) with a concurrent increase (26 percent mean gain from Vista to Patrick) in the concentration of dissolved phosphorus. This trend is attributed chicfly to the dissolution of particulate phosphorus by various biological processes, and to the uptake of DP by the aquatic plants. Other complex hydrologic factors also may play an important role in phosphorus cycling.

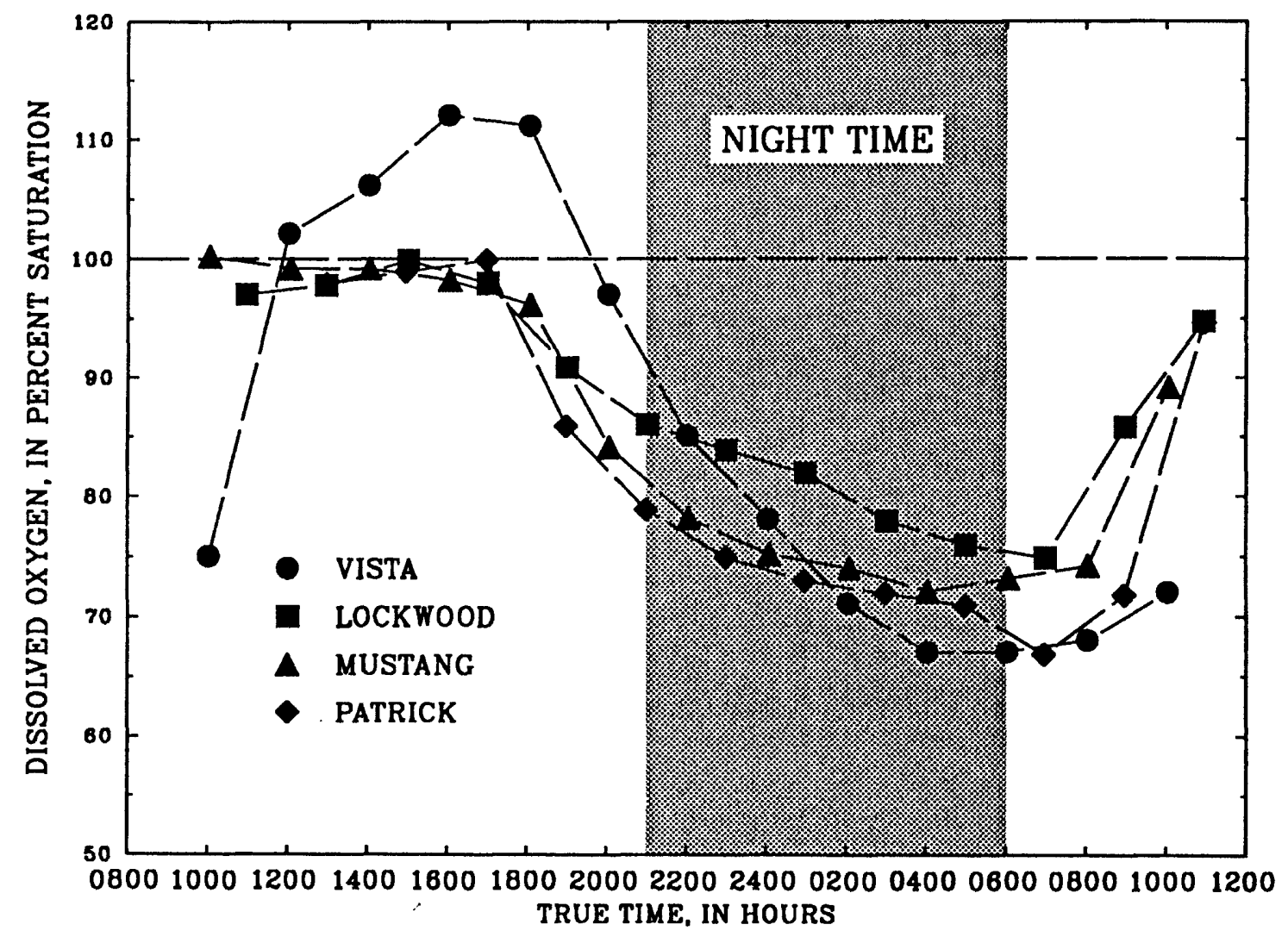

FIGURE 10.--Dissolved-oxygen saturation percentage in river during the diel study of August 15-16, 1984. Dashed line shows 100-percent saturation. 


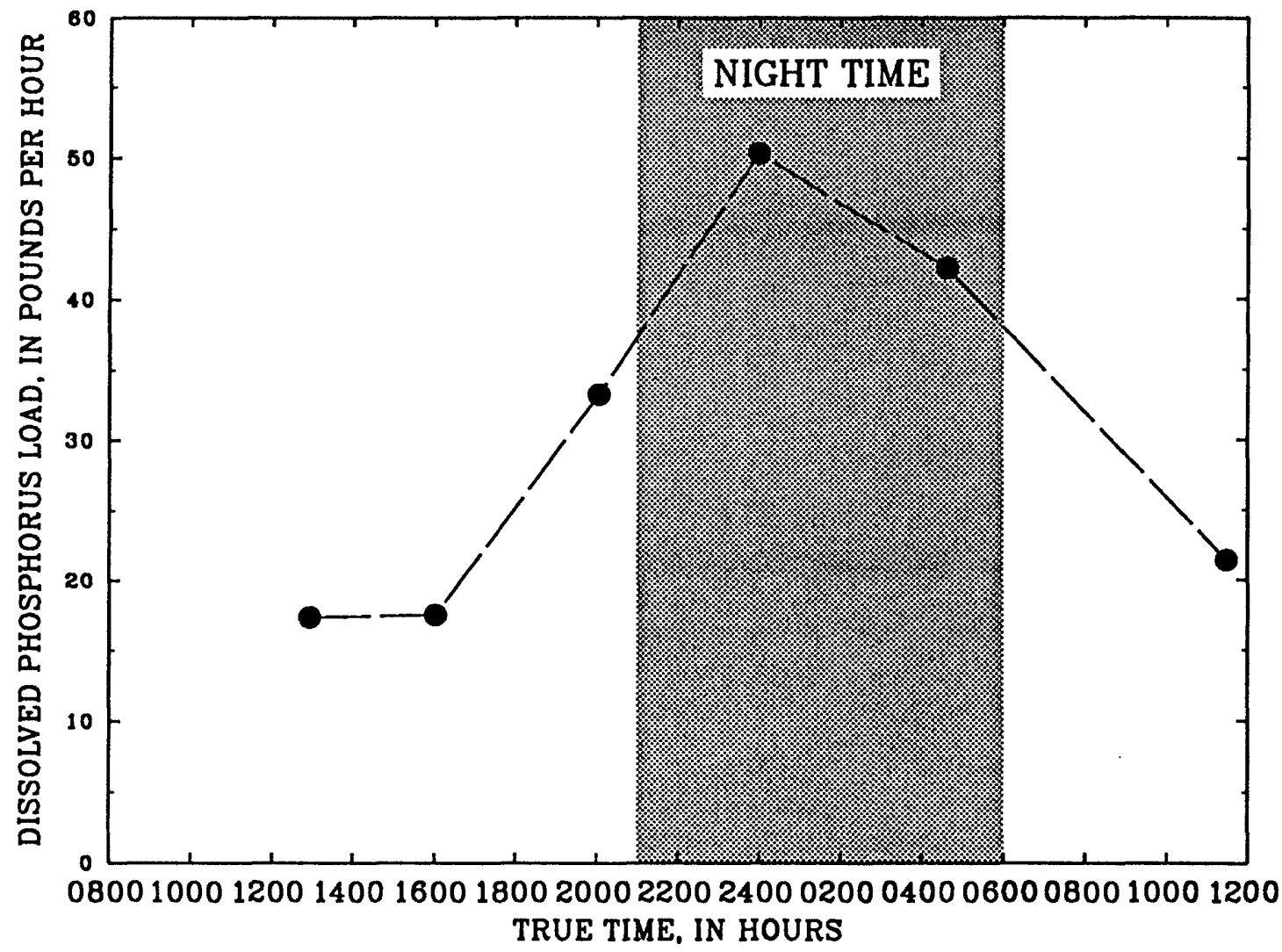

FIGURE 11.--Dissolved-phosphorus load in effluent from Reno-Sparks wastewater treatment plant during the diel study of August 13-14, 1980. Streamflow at Vista gage was about 300 cubic feet per second. 


\section{COMPARISON OF PREVIOUS DATA WITH THE RESULTS OF THIS STUDY}

A cursory examination of phosphorus data collected before the present study tended to support the idea of an accretion of phosphorus between Lockwood and Patrick. To adequately explain the apparent increase required a detailed revicw of past and ongoing sampling protocol by the various private and governmental agencies. Table 5 summarizes past data-collection activities concerning the Truckee River from Vista to Tracy.

Of the 31 data sets listed in table 5, and without any consideration given to whether a phosphorus difference of a tenth or a hundredth of a milligram per liter is significant, 17 data sets, or 55 percent, show a downstream increase of total phosphorus at Patrick relative to Vista. Of these 17 data sets, 9 represent streamflow from 1,000 to about $6,000 \mathrm{ft}^{3} / \mathrm{s}$. Because of the known high positive correlation of total phosphorus with suspended sediment (Feltz, 1984), and considering the potential for not obtaining representative whole-water samples when grab-sampling techniques are used, the apparent increase in TP at Patrick during high-flow conditions is probably the combined result of (1) dissolution or resuspension of phosphorus-bound particulate matter transported as bedload, and (2) underestimation of true suspended-phosphorus concentrations due to nonideal sampling methods.

The remaining eight data sets that showed an increase in TP at Patrick are examined in greater detail, as follows.

\section{Pacific Environmental Laboratory:}

(1) October 1977. These data were collected during a drought year, at flow of $64 \mathrm{ft}^{3} / \mathrm{s}$. Conditions during this period of low flow would not be expected to mirror those during the 24-hour period reported herein (flow, about $300 \mathrm{ft}^{3} / \mathrm{s}$ ).

(2) December 1977 and February 1978. These data were collected during the cool late-autumn and winter months of reduced biological activity. As mentioned earlier, a single grab sample for totalphosphorus analysis may not be truly representative of the cross section. Furthermore, as was shown in figures $4 \mathrm{~A}-5 \mathrm{~B}$, traveltime may have accounted for the apparent increase at a downstream station, especially when the sampling interval was short. In this instance, the interval between the sampling sites was only $1 / 2$ hour or less.

\section{Desert Research Institute:}

(1) October 1983. Nonrepresentative sampling techniques at Vista may have biased the analytical results when compared with the relatively well-mixed streamflow at Tracy. "Higher" concentrations may also be reported at Tracy if traveltime is not considered with respect to sampling protocol or with respect to subsequent interpretation of the analytical results.

Nevada Division of Environmental Protection:

(1) July 1984. These data represent single values for multiple samples composited over a 24-hour period. A difference of only $0.01 \mathrm{mg} / \mathrm{L}$ is insignificant, considering potential sampling and measurement error. 


\section{U.S. Geological Survey:}

(1) June 1979. These synoptic data are for grab samples collected at the centroid of flow. Although better than grab samples from the bank, this procedure was known at the time to be inferior to depthintegrating techniques across the channel. The data represent the concentration of TP from dawn to dusk; no samples were collected through the night. If the individual sample-collection times for Patrick are adjusted by the estimated traveltime ( 4 hours at $470 \mathrm{ft}^{3} / \mathrm{s}$ ), then the results indicate that the values used to calculate an arithmetic mean concentration for Patrick were, in reality, the concentrations "seen" at Lockwood 4 hours earlier. In addition, the puzzling absence of attendant increases in certain other hydrologic variables, such as specific conductance, that one might expect from a major external input, tends to invalidate the contention that a substantial input is real.

(2) August 1979. The water samples in this synoptic study were collected by grab sampling at the centroid of flow over a 24-hour period. Because phosphorus was analyzed in a filtered sample only, the total-phosphorus values (and their arithmetic mean) were derived by solving a linear-regression equation for all paired DP and TP values in the U.S. Geological Survey computerized data file for the Truckee River (Nowlin, 1987, p. 388). (Many of these data were from samples collected at sites downstream from Mustang.) Regardless of the lack of laboratory determinations of TP for Lockwood and Patrick, apparently the fairly large increase in concentration (about $0.3 \mathrm{mg} / \mathrm{L} \mathrm{TP}$ ) observed at Patrick (table 5) is an artifact of sampling and time-of-travel idiosyncrasies. For example, because the estimated traveltime between Lockwood and Patrick was 6.6 hours [this value was used in the TRWQ model (Nowlin, 1987)], the six highest concentrations at Patrick on August 8, 1979 (0.97, 1.1, 1.3, 1.3, 0.96, and $0.80 \mathrm{mg} / \mathrm{L}$ : La Camera and others, 1985, p. 48), probably represented the phosphorus that had passed through Lockwood before the first water sample had been collected there, at 1:00 p.m. (1300 hours).

(3) August 1980. The same basic rationale described in the foregoing paragraph can be applied to this data set with regard to the two initial high values $(0.95$ and $0.77 \mathrm{mg} / \mathrm{L} \mathrm{TP})$ that outlie the rest of the TP data set for Patrick on August 13 (La Camera and others, 1985, p. 48). Subtracting a traveltime of 6.3 hours [the estimate used in the TRWQ model (Nowlin, 1987)] from the individual samplecollection times at Patrick would place a flow parcel at Lockwood before the sampling crew even arrived. Ignoring the two uncharacteristically high TP values for Patrick and the anomalously low $0.18 \mathrm{mg} / \mathrm{L}$ from the Lockwood data set (La Camera and others, 1985, p. 45), would result in an arithmetic mean value of $0.48 \mathrm{mg} / \mathrm{L}$ TP at both stations. Again, a concomitant increase in other water-quality variables was not observed in the August data set to support an input from an external source.

To summarize the foregoing discussion of previous data, the occasional apparent increase in phosphorus concentration from Lockwood to Patrick, as suggested by data collected previous to the present study, is probably the result of several natural and man-caused factors including traveltime, high streamflow, and sampling protocol. 


\section{SUMMARY AND CONCLUSIONS}

During the calibration phase of a mathematical water-quality model of the lower Truckee River, the modeling results indicated that a phosphorus input ranging from about 200 to $500 \mathrm{lb} / \mathrm{d}$, of unknown source, would be required in the 5.13-mile reach from Lockwood to Patrick downstream from Reno to duplicate measured concentrations. The magnitude of the undocumented accretion was about 2- to 5-fold greater than the planned post-expansion loads from the wastewater treatment plant near Reno. Subsequent interpretation of hydrologic data from past sampling programs tended to support the observed increase in phosphorus at Patrick.

In August 1984, an intensive data-collection program was carried out, in cooperation with the Nevada Division of Environmental Protection, to ascertain whether the apparent input of phosphorus was real, or whether it was instead an artifact caused by the river's time-of-travel or to sampling procedures, or both. The data-collection program involved making instantaneous streamflow measurements about every 3 hours and collecting water samples using depth-integrating techniques across the stream every 2 hours during a diel period (nearly equivalent to a 24-hour time span). The hydrologic data were collected from four stations along a 7.31mile reach from Vista to Patrick. Water-quality variables included total and dissolved phosphorus; dissolved chloride, sulfate, and arsenic; and specific conductance, dissolved oxygen, temperature, and $\mathrm{pH}$.

Analysis of the data collected during the diel study indicated that steady-state flow conditions prevailed. In addition, virtually no change in the concentration of conservative constituents and properties--chloride, sulfate, and specific conductance--was evident either with time or with space. The concentration of arsenic also remained constant with time and space. These observations strongly indicate the absence of a substantial fluctuation in ground-water inflow during this study.

Although the concentration of total phosphorus varied greatly, and somewhat predictably, in response to the natural daily rhythm (being highest during the night with reduced biological activity and lowest during the daytime with active photosynthesis), no overall downstream increase was observed at Patrick. Dissolved phosphorus, like total phosphorus, reflected a 24-hour daily cycle, in response to variations in loads from the RenoSparks sewage outfall and to nutrient uptake by the aquatic plants during the daytime. Unlike total phosphorus, however, a slight but noticeable trend of downstream increase in concentration was seen. The trend is attributed to the dissolution of the suspended (or particulate) fraction in the river.

The results of the present study appear to refute the existence of a nonpoint source of phosphorus between Lockwood and Patrick, and suggest instead that the apparent phosphorus increase was due primarily to sampling protocol and time-of-travel phenomena compounded by fluctuating phosphorus discharges from the Reno-Sparks joint wastewater facility. The results of this study, however, are not necessarily applicable to other reaches of the Truckee River or to other periods of time, or to both.

The TP-assimilation rate in this study ( 0.20 per day) was comparable with that used in the 1979-80 U.S. Geological Survey water-quality model ( 0.25 per day; Nowlin, 1987, p. 175). Downstream increases of the dissolved fraction within decreasing total phosphorus indicates that dissolution of the phosphorus was occurring in association with other instream processes. This suggests that the probable error associated with non-integrated sampling (that is, grab samples that underestimate total-phosphorus concentration) probably decreases from Vista to Patrick. Consequently, the historical data probably underestimate TP for sampling stations upstream from Patrick. 
Sources of suspended phosphorus may be the wastewater treatment plant or other upstream sources-Steamboat Creek, for example. Substantial quantities of suspended phosphorus from these sources would cause an underestimation of model inputs for the U.S. Geological Survey 1979-80 synoptic-data sets. Because the purpose of this study was to look for a phosphorus input within a specific reach of the river, the identification and quantification of phosphorus sources upstream from the study reach was not attempted.

This short-term study re-emphasizes the need to collect representative water samples using accepted methods (Keup, 1968). The use of cross channel, depth-integrating procedures in the Truckee River, especially during high-flow conditions, is necessary for the determination of phosphorus as well as other elements of interest, such as trace elements and organics, that are commonly bound to suspended particulate matter (U.S. Geological Survey, 1977). 
HYDROLOGIC DATA 
TABLE 5.--Selected hydrologic data for reach from Vista to Tracy, October 1977 through August 1984

[Abbreviations: BR, bridge; cntr, centroid of flow: DI, depth-integrated across stream; ft ${ }^{3} / \mathrm{s}$, cublc feet per second; LB, left bank, facing downstream; mg/L, milligrams per 11ter; 2-hr and 4-hr, sampling frequency; -- , no value available]

\begin{tabular}{|c|c|c|c|c|c|c|c|c|}
\hline \multirow[t]{3}{*}{.} & & & & & Total & & Dis- & \\
\hline & & & & & ortho- & Total & solved & \\
\hline & Time & & & & phos- & phos- & phos- & \\
\hline Date & $\begin{array}{l}\text { (24- } \\
\text { hour) }\end{array}$ & station & $\begin{array}{c}\text { Discharge } \\
\left(\mathrm{ft}^{3} / \mathrm{s}\right)\end{array}$ & Sampling method & $\begin{array}{l}\text { phorus } \\
\text { (mg/L) }\end{array}$ & $\begin{array}{l}\text { phorus } \\
\text { (mg/L) }\end{array}$ & $\begin{array}{c}\text { phorus } \\
\text { (mg/L) }\end{array}$ & Remarks \\
\hline
\end{tabular}

\section{PACIFIC ENVIRONMENTAL LABORATORY}

\begin{tabular}{|c|c|c|c|c|c|c|c|c|}
\hline Oct. & 14,19 & & $\begin{array}{l}2200 \\
2230 \\
2310\end{array}$ & $\begin{array}{l}\text { Vista } \\
\text { Lockwood } \\
\text { Patrick }\end{array}$ & $\begin{array}{l}64 \\
--\end{array}$ & $\begin{array}{l}\text { single } 9 \\
\text { single } 9 \\
\text { single } 9\end{array}$ & $\begin{array}{l}\text { grat } \\
\text { grat } \\
\text { grat }\end{array}$ & \\
\hline Dec. & 12,19 & & $\begin{array}{l}1200 \\
1220 \\
1250\end{array}$ & $\begin{array}{l}\text { V1sta } \\
\text { Lockwood } \\
\text { Patrick }\end{array}$ & $\begin{array}{l}140 \\
--\end{array}$ & $\begin{array}{l}\text { Single g } \\
\text { single g } \\
\text { Single g }\end{array}$ & $\begin{array}{l}\text { grak } \\
\text { grab } \\
\text { grat }\end{array}$ & \\
\hline Feb. & 21,19 & & $\begin{array}{l}1330 \\
1400 \\
1425\end{array}$ & $\begin{array}{l}\text { Vista } \\
\text { Lockwood } \\
\text { Patrick }\end{array}$ & $\stackrel{490}{--}$ & $\begin{array}{l}\text { single g } \\
\text { single } 9 \\
\text { single } 9\end{array}$ & $\begin{array}{l}\text { grab } \\
\text { grat } \\
\text { grat }\end{array}$ & \\
\hline May & $3-4, \quad 19$ & & $\begin{array}{l}0800 \\
\text { to } \\
0800\end{array}$ & $\begin{array}{l}\text { Vista } \\
\text { Lockwood } \\
\text { Patrick }\end{array}$ & $\begin{array}{r}1,550 \\
-- \\
--\end{array}$ & \multicolumn{3}{|c|}{$\begin{array}{l}\text { Composite grab } \\
\text { Composite grab } \\
\text { Composite grab }\end{array}$} \\
\hline June & 28-29, & 1978 & $\begin{array}{l}0600 \\
\text { to } \\
0600\end{array}$ & $\begin{array}{l}\text { Vista } \\
\text { Lockwood } \\
\text { Patrick }\end{array}$ & $\begin{array}{c}460 \\
--\end{array}$ & $\begin{array}{l}\text { Composit } \\
\text { Composit } \\
\text { Composit }\end{array}$ & $\begin{array}{l}\text { te } \\
\text { te } 9 \\
\text { te } g\end{array}$ & $\begin{array}{l}\text { gra } \\
\text { gra } \\
\text { gra }\end{array}$ \\
\hline Aug. & $28-29$, & 1978 & $\begin{array}{l}0800 \\
\text { to } \\
0800\end{array}$ & $\begin{array}{l}\text { Vista } \\
\text { Lockwood } \\
\text { Patrick }\end{array}$ & $\begin{array}{r}280 \\
--\end{array}$ & $\begin{array}{l}\text { Composit } \\
\text { Composit } \\
\text { Composit }\end{array}$ & $\begin{array}{l}\text { te } \\
\text { te } g \\
\text { te }\end{array}$ & $g 1$ \\
\hline
\end{tabular}

DESERT RESEARCH INSTITUTE

\begin{tabular}{|c|c|c|c|c|c|c|}
\hline March 2, 1983 & $\begin{array}{l}1020 \\
1100\end{array}$ & $\begin{array}{l}\text { Vista } \\
\text { Tracy }\end{array}$ & $\begin{array}{l}3,500 \\
3,050\end{array}$ & $\begin{array}{l}\text { Single } \\
\text { single }\end{array}$ & $\begin{array}{l}\text { grab, } \\
\text { grab, }\end{array}$ & $\begin{array}{l}\text { LB } \\
\text { BR }\end{array}$ \\
\hline April 6, 1983 & $\begin{array}{l}1100 \\
1145\end{array}$ & $\begin{array}{l}\text { Vista } \\
\text { Tracy }\end{array}$ & $\begin{array}{l}3,000 \\
3,140\end{array}$ & $\begin{array}{l}\text { Single } \\
\text { single }\end{array}$ & $\begin{array}{l}\text { grab, } \\
\text { grab, }\end{array}$ & $\begin{array}{l}\mathrm{LB} \\
\mathrm{BR}\end{array}$ \\
\hline May 4, 1983 & $\begin{array}{l}1130 \\
1200\end{array}$ & $\begin{array}{l}\text { Vista } \\
\text { Tracy }\end{array}$ & $\begin{array}{l}3,790 \\
3,690\end{array}$ & $\begin{array}{l}\text { Single } \\
\text { single }\end{array}$ & $\begin{array}{l}\text { grab, } \\
\text { grab, }\end{array}$ & $\begin{array}{l}\mathrm{LB} \\
\mathrm{BR}\end{array}$ \\
\hline June 1,1983 & $\begin{array}{l}1030 \\
1100\end{array}$ & $\begin{array}{l}\text { Vista } \\
\text { Tracy }\end{array}$ & $\begin{array}{l}6,290 \\
5,430\end{array}$ & $\begin{array}{l}\text { Single } \\
\text { single }\end{array}$ & $\begin{array}{l}\text { grab, } \\
\text { grab, }\end{array}$ & $\begin{array}{l}\text { LB } \\
\text { BR }\end{array}$ \\
\hline July 6,1983 & $\begin{array}{l}1100 \\
1130\end{array}$ & $\begin{array}{l}\text { Vista } \\
\text { Tracy }\end{array}$ & $\begin{array}{l}3,800 \\
3,630 .\end{array}$ & $\begin{array}{l}\text { Single } \\
\text { single }\end{array}$ & $\begin{array}{l}\text { grab, } \\
\text { grab, }\end{array}$ & $\begin{array}{l}\mathrm{LB} \\
\mathrm{BR}\end{array}$ \\
\hline Aug. 3, 1983 & $\begin{array}{l}1100 \\
1140\end{array}$ & $\begin{array}{l}\text { Vista } \\
\text { Tracy }\end{array}$ & $\begin{array}{l}1,050 \\
1,000\end{array}$ & $\begin{array}{l}\text { Single } \\
\text { single }\end{array}$ & $\begin{array}{l}\text { grab, } \\
\text { grab, }\end{array}$ & $\begin{array}{l}\mathrm{LB} \\
\mathrm{BR}\end{array}$ \\
\hline Sept. 7, 1983 & $\begin{array}{l}1300 \\
1330\end{array}$ & $\begin{array}{l}\text { Vista } \\
\text { Tracy }\end{array}$ & $\begin{array}{r}1,500 \\
--\end{array}$ & $\begin{array}{l}\text { Single } \\
\text { single }\end{array}$ & $\begin{array}{l}\text { grab, } \\
\text { grab, }\end{array}$ & $\begin{array}{l}\text { LB } \\
\text { BR }\end{array}$ \\
\hline Oct. 5, 1983 & $\begin{array}{l}1040 \\
1120\end{array}$ & $\begin{array}{l}\text { Vista } \\
\text { Tracy }\end{array}$ & $\begin{array}{r}500 \\
--\end{array}$ & $\begin{array}{l}\text { Single } \\
\text { Single }\end{array}$ & $\begin{array}{l}\text { grab, } \\
\text { grab, }\end{array}$ & $\begin{array}{l}\mathrm{LB} \\
\mathrm{BR}\end{array}$ \\
\hline Nov. 2, 1983 & $\begin{array}{l}0930 \\
1010\end{array}$ & $\begin{array}{l}\text { Vista } \\
\text { Tracy }\end{array}$ & $\begin{array}{r}1,300 \\
--\end{array}$ & $\begin{array}{l}\text { Single } \\
\text { Single }\end{array}$ & $\begin{array}{l}\text { grab, } \\
\text { grab, }\end{array}$ & $\begin{array}{l}\mathrm{LB} \\
\mathrm{BR}\end{array}$ \\
\hline Dec. 7,1983 & $\begin{array}{l}0930 \\
1010\end{array}$ & $\begin{array}{l}\text { Vista } \\
\text { Tracy }\end{array}$ & $\begin{array}{r}3,400 \\
--\end{array}$ & $\begin{array}{l}\text { Single } \\
\text { Single }\end{array}$ & $\begin{array}{l}\text { grab, } \\
\text { grab, }\end{array}$ & $\begin{array}{l}\mathrm{LB} \\
\mathrm{BR}\end{array}$ \\
\hline $\operatorname{Jan} .12,1984$ & $\begin{array}{l}1100 \\
1140\end{array}$ & $\begin{array}{l}\text { Vista } \\
\text { Tracy }\end{array}$ & $\begin{array}{r}3,200 \\
--\end{array}$ & $\begin{array}{l}\text { Single } \\
\text { Single }\end{array}$ & $\begin{array}{l}\text { grab, } \\
\text { grab, }\end{array}$ & $\begin{array}{l}\text { LB } \\
\text { BR }\end{array}$ \\
\hline Feb. 1,1984 & $\begin{array}{l}0930 \\
1020\end{array}$ & $\begin{array}{l}\text { Vista } \\
\text { Tracy }\end{array}$ & 2,600 & $\begin{array}{l}\text { Single } \\
\text { single }\end{array}$ & $\begin{array}{l}\text { grab, } \\
\text { grab, }\end{array}$ & $\begin{array}{l}\text { LB } \\
\text { BR }\end{array}$ \\
\hline March 7, 1984 & $\begin{array}{l}1025 \\
1115\end{array}$ & $\begin{array}{l}\text { Vista } \\
\text { Tracy }\end{array}$ & $\begin{array}{r}1,900 \\
--\end{array}$ & $\begin{array}{l}\text { Single } \\
\text { Single }\end{array}$ & $\begin{array}{l}\text { grab, } \\
\text { grab, }\end{array}$ & $\begin{array}{l}\text { LB } \\
\text { BR }\end{array}$ \\
\hline April 4, 1984 & $\begin{array}{l}1015 \\
1050\end{array}$ & $\begin{array}{l}\text { Vista } \\
\text { Tracy }\end{array}$ & $\begin{array}{r}1,300 \\
--\end{array}$ & $\begin{array}{l}\text { Single } \\
\text { single }\end{array}$ & $\begin{array}{l}\text { grab, } \\
\text { grab, }\end{array}$ & $\begin{array}{l}\mathrm{LB} \\
\mathrm{BR}\end{array}$ \\
\hline May 2, 1984 & $\begin{array}{l}1025 \\
1120\end{array}$ & $\begin{array}{l}\text { Vista } \\
\text { Tracy }\end{array}$ & 1,000 & $\begin{array}{l}\text { Single } \\
\text { Single }\end{array}$ & $\begin{array}{l}\text { grab, } \\
\text { grab, }\end{array}$ & $\begin{array}{l}\mathrm{LB} \\
\mathrm{BR}\end{array}$ \\
\hline
\end{tabular}

$\begin{array}{cccl}2.50 & 2.60 & -- & \text { Extreme low flow } \\ -- & 1.80 & -- & \\ -- & 1.90 & -- & \\ .87 & 1.00 & -- & \text { Cool, late autumn } \\ 1.30 & 1.50 & -- & \\ 1.70 & 1.80 & -- & \\ .28 & .38 & -- & \text { Winter } \\ .24 & .48 & -- & \\ .44 & .61 & -- & \\ .08 & .17 & -- & \text { High flow } \\ .10 & .19 & -- & \\ .11 & .24 & - & \\ .35 & .39 & -- & \\ .30 & .36 & -- & \\ .26 & .32 & -- & \\ .80 & .86 & -- & \\ .72 & .72 & -- & \\ .69 & .69 & - & \end{array}$

\begin{tabular}{|c|c|c|c|c|}
\hline $\begin{array}{r}0.04 \\
.05\end{array}$ & $\begin{array}{r}0.08 \\
.11\end{array}$ & -- & High & flow \\
\hline $\begin{array}{l}.02 \\
.02\end{array}$ & $\begin{array}{l}.06 \\
.09\end{array}$ & $=$ & High & flow \\
\hline $\begin{array}{l}.01 \\
.01\end{array}$ & $\begin{array}{l}.06 \\
.06\end{array}$ & $=$ & High & flow \\
\hline $\begin{array}{l}.02 \\
.03\end{array}$ & $\begin{array}{l}.15 \\
.19\end{array}$ & - & High & flow \\
\hline $\begin{array}{l}.03 \\
.02\end{array}$ & $\begin{array}{l}.10 \\
.13\end{array}$ & 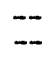 & High & flow \\
\hline $\begin{array}{l}.04 \\
.04\end{array}$ & $\begin{array}{l}.12 \\
.12\end{array}$ & -- & High & flow \\
\hline $\begin{array}{l}.04 \\
.05\end{array}$ & $\begin{array}{l}.12 \\
.11\end{array}$ & -- & H1gh & flow \\
\hline $\begin{array}{l}.04 \\
.07\end{array}$ & $\begin{array}{l}.13 \\
.16\end{array}$ & -- & & \\
\hline $\begin{array}{l}.04 \\
.03\end{array}$ & $\begin{array}{l}.10 \\
.12\end{array}$ & $\vec{m}$ & High & flow \\
\hline $\begin{array}{l}.02 \\
.03\end{array}$ & $\begin{array}{l}.08 \\
.07\end{array}$ & -- & High & flow \\
\hline $\begin{array}{l}.01 \\
.02\end{array}$ & $\begin{array}{l}.05 \\
.05\end{array}$ & $=$ & High & flow \\
\hline $\begin{array}{l}.02 \\
.03\end{array}$ & $\begin{array}{l}.05 \\
.07\end{array}$ & -- & High & flow \\
\hline $\begin{array}{l}.02 \\
.02\end{array}$ & $\begin{array}{l}.05 \\
.05\end{array}$ & $=$ & High & flow \\
\hline $\begin{array}{l}.01 \\
.02\end{array}$ & $\begin{array}{l}.09 \\
.09\end{array}$ & -- & $\mathrm{High}$ & flow \\
\hline $\begin{array}{l}.07 \\
.10\end{array}$ & $\begin{array}{l}.12 \\
.16\end{array}$ & $=$ & High & flow \\
\hline
\end{tabular}


TABLE 5.--Selected hydrologic data for reach from Vista to Tracy, October 1977 through August $1984--$ Continued

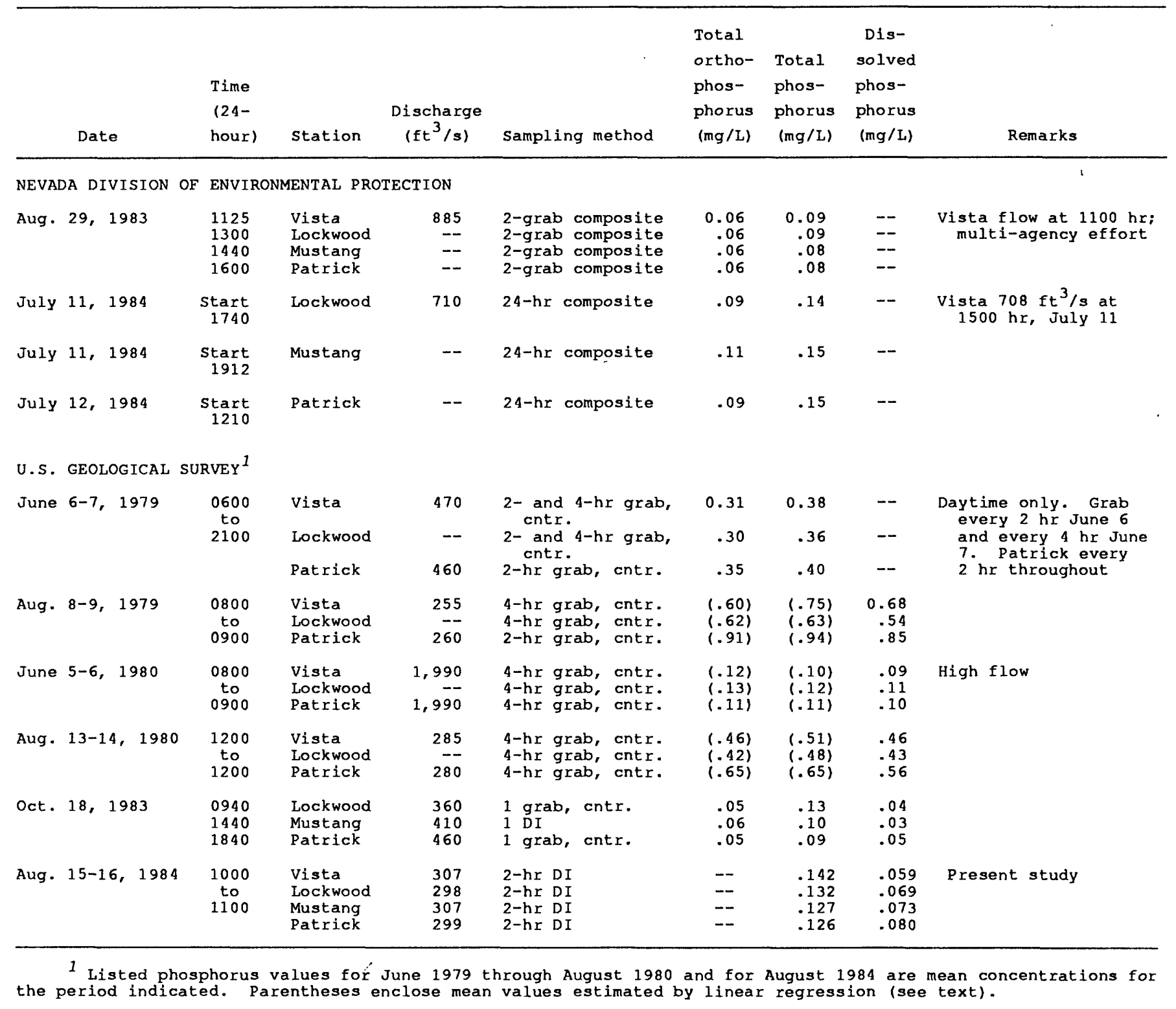


TABLE 6.--Hydrologic data for diel study of August 15-16, 1984

[Abbreviations: $\mathrm{E}$, estimated; $\mathrm{ft}^{3} / \mathrm{s}$, cubic feet per second; $\mathrm{mg} / \mathrm{L}$, $\mathrm{milligrams}$ per liter; $\mathrm{mm}$ of $\mathrm{Hg}$, millimeters of mercury; ${ }^{\circ} \mathrm{C}$, degrees Celsius; $\mu \mathrm{g} / \mathrm{L}$, micrograms per liter; $\mu \mathrm{S} / \mathrm{cm}$, microsiemens per centimeter at $25^{\circ} \mathrm{C} ;--$, no value available]

\begin{tabular}{|c|c|c|c|c|c|c|}
\hline Date & Time & $\begin{array}{l}\text { Temperature, } \\
\text { water } \\
\left({ }^{\circ} \mathrm{C}\right)\end{array}$ & $\begin{array}{c}\text { Barometric } \\
\text { pressure } \\
(\mathrm{mm} \text { of } \mathrm{Hg})\end{array}$ & $\begin{array}{c}\text { streamflow, } \\
\text { instantaneous } \\
\left(\mathrm{ft}^{3} / \mathrm{s}\right)\end{array}$ & $\begin{array}{c}\text { Specific } \\
\text { conductance } \\
(\mu \mathrm{S} / \mathrm{cm})\end{array}$ & $\begin{array}{l}\text { Oxygen, } \\
\text { dissolvec } \\
\text { (mg/L) }\end{array}$ \\
\hline & & Truc & River at & Vista, Nevada & & \\
\hline $08 / 15 / 84$ & $\begin{array}{l}1000 \\
1200 \\
1400 \\
1600 \\
1800 \\
2000 \\
2200 \\
2400\end{array}$ & $\begin{array}{l}20.5 \\
20.5 \\
21.0 \\
21.0 \\
22.0 \\
22.0 \\
21.5 \\
21.0\end{array}$ & $\begin{array}{l}650 \\
650 \\
650 \\
650 \\
650 \\
650 \\
650 \\
650\end{array}$ & $\begin{array}{l}298 \\
311 \\
314 \\
314 \\
313 \\
316 \\
317 \\
305\end{array}$ & $\begin{array}{l}295 \\
290 \\
270 \\
275 \\
280 \\
275 \\
280 \\
285\end{array}$ & $\begin{array}{l}5.7 \\
7.8 \\
8.0 \\
8.5 \\
8.2 \\
7.2 \\
6.4 \\
5.9\end{array}$ \\
\hline \multirow[t]{2}{*}{$08 / 16 / 84$} & $\begin{array}{l}0200 \\
0400 \\
0600 \\
0800 \\
1000\end{array}$ & $\begin{array}{l}20.0 \\
19.0 \\
19.0 \\
18.0 \\
18.5\end{array}$ & $\begin{array}{l}650 \\
652 \\
652 \\
653 \\
654\end{array}$ & $\begin{array}{l}301 \\
301 \\
301 \\
301 \\
302\end{array}$ & $\begin{array}{l}280 \\
310 \\
290 \\
300 \\
265\end{array}$ & $\begin{array}{l}5.5 \\
5.3 \\
5.3 \\
5.5 \\
5.8\end{array}$ \\
\hline & & Trucl & River at & ockwood, Nevada & & \\
\hline $08 / 15 / 84$ & $\begin{array}{l}1100 \\
1300 \\
1500 \\
1700 \\
1900 \\
2100 \\
2300\end{array}$ & $\begin{array}{l}21.0 \\
21.0 \\
21.0 \\
21.0 \\
21.0 \\
21.0 \\
21.0\end{array}$ & $\begin{array}{l}641 \\
651 \\
651 \\
651 \\
651 \\
650 \\
651\end{array}$ & $\begin{array}{l}291 \\
285 \\
291 \\
304 \\
305 \\
302 \\
300\end{array}$ & $\begin{array}{l}285 \\
275 \\
290 \\
290 \\
300 \\
290 \\
310\end{array}$ & $\begin{array}{l}7.2 \\
7.4 \\
7.6 \\
7.4 \\
6.9 \\
6.5 \\
6.4\end{array}$ \\
\hline $08 / 16 / 84$ & $\begin{array}{l}0100 \\
0300 \\
0500 \\
0700 \\
0900 \\
1100\end{array}$ & $\begin{array}{l}21.0 \\
20.0 \\
18.0 \\
18.5 \\
18.5 \\
19.0\end{array}$ & $\begin{array}{l}652 \\
651 \\
651 \\
652 \\
652 \\
653\end{array}$ & $\begin{array}{l}296 \\
295 \\
299 \\
302 \\
304 \\
304\end{array}$ & $\begin{array}{l}310 \\
310 \\
310 \\
295 \\
280 \\
290\end{array}$ & $\begin{array}{l}6.2 \\
6.0 \\
6.1 \\
6.0 \\
6.9 \\
7.5\end{array}$ \\
\hline
\end{tabular}

Truckee River at Mustang Bridge No. 1 near Hafed, Nevada

\begin{tabular}{|c|c|c|c|c|c|c|}
\hline $08 / 15 / 84$ & $\begin{array}{l}1000 \\
1200 \\
1400 \\
1600 \\
1800 \\
2000 \\
2200 \\
2400\end{array}$ & $\begin{array}{l}21.5 \\
22.0 \\
21.5 \\
21.5 \\
21.5 \\
21.0 \\
20.5 \\
20.5\end{array}$ & $\begin{array}{l}654 \\
654 \\
652 \\
653 \\
652 \\
652 \\
653 \\
654\end{array}$ & $\begin{array}{r}\text { E314 } \\
313 \\
313 \\
310 \\
\text { E310 } \\
312 \\
308 \\
302\end{array}$ & $\begin{array}{l}295 \\
300 \\
262 \\
269 \\
272 \\
280 \\
284 \\
290\end{array}$ & $\begin{array}{l}7.5 \\
7.4 \\
7.4 \\
7.4 \\
7.2 \\
6.4 \\
6.0 \\
5.8\end{array}$ \\
\hline \multirow[t]{2}{*}{$08 / 16 / 84$} & $\begin{array}{l}0200 \\
0400 \\
0600 \\
0800 \\
1000\end{array}$ & $\begin{array}{l}20.5 \\
20.0 \\
19.5 \\
19.0 \\
19.0\end{array}$ & $\begin{array}{l}654 \\
654 \\
654 \\
654 \\
656\end{array}$ & $\begin{array}{r}300 \\
297 \\
301 \\
304 \\
\text { E307 }\end{array}$ & $\begin{array}{l}297 \\
298 \\
291 \\
298 \\
275\end{array}$ & $\begin{array}{l}5.7 \\
5.6 \\
5.7 \\
5.9 \\
7.1\end{array}$ \\
\hline & \multicolumn{6}{|c|}{ Truckee River at Patrick, Nevada } \\
\hline $08 / 15 / 84$ & $\begin{array}{l}1100 \\
1300 \\
1500 \\
1700 \\
1900 \\
2100 \\
2300\end{array}$ & $\begin{array}{l}21.0 \\
22.0 \\
22.0 \\
21.5 \\
20.5 \\
20.0 \\
19.0\end{array}$ & $\begin{array}{l}654 \\
653 \\
652 \\
651 \\
651 \\
653 \\
653\end{array}$ & $\begin{array}{l}284 \\
287 \\
290 \\
296 \\
310 \\
312 \\
305\end{array}$ & $\begin{array}{l}300 \\
295 \\
295 \\
280 \\
280 \\
283 \\
280\end{array}$ & $\begin{array}{l}7 .- \\
7.3 \\
7.4 \\
7.5 \\
6.6 \\
6.1 \\
5.9\end{array}$ \\
\hline $08 / 16 / 84$ & $\begin{array}{l}0100 \\
0300 \\
0500 \\
0700 \\
0900 \\
1100\end{array}$ & $\begin{array}{l}19.0 \\
19.0 \\
19.0 \\
19.0 \\
19.0 \\
20.0\end{array}$ & $\begin{array}{l}653 \\
653 \\
654 \\
654 \\
655 \\
655\end{array}$ & $\begin{array}{l}299 \\
293 \\
293 \\
300 \\
306 \\
310\end{array}$ & $\begin{array}{l}280 \\
280 \\
280 \\
290 \\
290 \\
283\end{array}$ & $\begin{array}{l}5.8 \\
5.7 \\
5.6 \\
5.3 \\
5.7 \\
7.4\end{array}$ \\
\hline
\end{tabular}


TABLE 6.--Hydrologic data for diel study of August 15-16, 1984--Cont1nued

\begin{tabular}{|c|c|c|c|c|c|c|c|}
\hline Date & $\begin{array}{c}\mathrm{pH} \\
\text { (standard } \\
\text { units) }\end{array}$ & $\begin{array}{c}\text { Phosphorus, } \\
\text { total } \\
\text { (mg/L } \\
\text { as } P \text { ) }\end{array}$ & $\begin{array}{c}\text { Phosphorus, Ch } \\
\text { dissolved } \\
\text { (mg/L } \\
\text { as P) }\end{array}$ & $\begin{array}{l}\text { loride, } \\
\text { issolved } \\
\text { (mg/L } \\
\text { as Cl) }\end{array}$ & \multicolumn{2}{|c|}{$\begin{array}{l}\text { Sulfate, } \\
\text { dissolved } \\
(\mathrm{mg} / \mathrm{L} \\
\left.\text { as } \mathrm{SO}_{4}\right)\end{array}$} & $\begin{array}{l}\text { Arsenic, } \\
\text { dissolved } \\
\text { (mg/L } \\
\text { as As) }\end{array}$ \\
\hline \multicolumn{8}{|c|}{ Truckee River at Vista, Nevada } \\
\hline $08 / 15 / 84$ & $\begin{array}{l}7.7 \\
7.8 \\
7.7 \\
7.8 \\
8.0 \\
8.1 \\
8.1 \\
8.2\end{array}$ & $\begin{array}{r}0.112 \\
.127 \\
.111 \\
.112 \\
.114 \\
.135 \\
.160 \\
.188\end{array}$ & $\begin{array}{r}0.055 \\
.051 \\
.049 \\
.053 \\
.058 \\
.067 \\
.073 \\
.074\end{array}$ & $\begin{array}{l}12 \\
14 \\
12 \\
12 \\
13 \\
14 \\
14 \\
13\end{array}$ & & $\begin{array}{l}22 \\
23 \\
23 \\
23 \\
23 \\
21 \\
23 \\
22\end{array}$ & $\begin{array}{ll}1 & 0 \\
1 & 0 \\
1 & 0 \\
1 & 0 \\
1 & 0 \\
1 & 1 \\
1 & 1 \\
1 & 0\end{array}$ \\
\hline \multirow[t]{2}{*}{$08 / 16 / 84$} & $\begin{array}{l}7.9 \\
7.9 \\
7.7 \\
7.7 \\
7.8\end{array}$ & $\begin{array}{l}.170 \\
.171 \\
.163 \\
.148 \\
.132\end{array}$ & $\begin{array}{l}.065 \\
.060 \\
.060 \\
.051 \\
.048\end{array}$ & $\begin{array}{l}13 \\
12 \\
12 \\
11 \\
11\end{array}$ & & $\begin{array}{l}22 \\
22 \\
22 \\
21 \\
22\end{array}$ & $\begin{array}{r}10 \\
8 \\
7 \\
7 \\
7\end{array}$ \\
\hline & \multicolumn{6}{|c|}{ Truckee River at Lockwood, Nevada } & \\
\hline $08 / 15 / 84$ & $\begin{array}{l}7.9 \\
8.1 \\
7.7 \\
8.0 \\
7.9 \\
8.1 \\
8.1\end{array}$ & $\begin{array}{r}0.122 \\
.109 \\
.108 \\
.102 \\
.104 \\
.114 \\
.132\end{array}$ & $\begin{array}{c}0.065 \\
.061 \\
.061 \\
.057 \\
.061 \\
.- \\
.079\end{array}$ & $\begin{array}{l}13 \\
12 \\
13 \\
12 \\
13 \\
13 \\
14\end{array}$ & & $\begin{array}{l}23 \\
22 \\
22 \\
23 \\
23 \\
22 \\
23\end{array}$ & $\begin{array}{ll}1 & 1 \\
1 & 1 \\
1 & 0 \\
1 & 0 \\
1 & 1 \\
12 & 2 \\
12\end{array}$ \\
\hline \multirow[t]{2}{*}{$08 / 16 / 84$} & $\begin{array}{l}8.2 \\
8.2 \\
8.1 \\
7.9 \\
7.9 \\
8.0\end{array}$ & $\begin{array}{l}.158 \\
.172 \\
.158 \\
.161 \\
.144 \\
.127\end{array}$ & $\begin{array}{l}.078 \\
.085 \\
.077 \\
.071 \\
.067 \\
.064\end{array}$ & $\begin{array}{l}14 \\
13 \\
12 \\
12 \\
12 \\
11\end{array}$ & & $\begin{array}{l}23 \\
22 \\
22 \\
22 \\
21 \\
22\end{array}$ & $\begin{array}{r}12 \\
11 \\
10 \\
9 \\
8 \\
7\end{array}$ \\
\hline & Truckee & River at Must & tang Bridge No. 1 & 1 near Ha & \multicolumn{2}{|c|}{ Hafed, Nevada } & \\
\hline $08 / 15 / 84$ & $\begin{array}{l}7.9 \\
8.0 \\
8.1 \\
8.1 \\
8.0 \\
7.9 \\
7.9 \\
7.9\end{array}$ & $\begin{array}{r}0.133 \\
.129 \\
.106 \\
.112 \\
.106 \\
.104 \\
.103 \\
.118\end{array}$ & $\begin{array}{r}0.075 \\
.077 \\
.065 \\
.065 \\
.061 \\
.061 \\
.065 \\
.078\end{array}$ & $\begin{array}{l}13 \\
12 \\
11 \\
11 \\
11 \\
12 \\
11 \\
13\end{array}$ & & $\begin{array}{l}24 \\
22 \\
20 \\
23 \\
24 \\
21 \\
21 \\
22\end{array}$ & $\begin{array}{r}11 \\
10 \\
11 \\
10 \\
9 \\
10 \\
10 \\
12\end{array}$ \\
\hline \multirow[t]{2}{*}{$08 / 16 / 84$} & $\begin{array}{l}8.0 \\
7.9 \\
7.9 \\
7.9 \\
8.0\end{array}$ & $\begin{array}{l}.133 \\
.152 \\
.154 \\
.156 \\
.148\end{array}$ & $\begin{array}{l}.082 \\
.088 \\
.082 \\
.079 \\
.074\end{array}$ & $\begin{array}{l}13 \\
14 \\
13 \\
11 \\
11\end{array}$ & & $\begin{array}{l}22 \\
24 \\
23 \\
22 \\
21\end{array}$ & $\begin{array}{r}11 \\
11 \\
10 \\
9 \\
8\end{array}$ \\
\hline & & Truckee $\mathrm{Ri}$ & iver at Patrick, & Nevada & & & \\
\hline $08 / 15 / 84$ & $\begin{array}{l}7.8 \\
8.1 \\
8.1 \\
7.8 \\
7.8 \\
7.8 \\
7.6\end{array}$ & $\begin{array}{r}0.136 \\
.120 \\
.120 \\
.109 \\
.109 \\
.111 \\
.116\end{array}$ & $\begin{array}{r}0.089 \\
.082 \\
.079 \\
.075 \\
.072 \\
.072 \\
.067\end{array}$ & $\begin{array}{l}14 \\
14 \\
14 \\
12 \\
13 \\
13 \\
12\end{array}$ & & $\begin{array}{l}24 \\
23 \\
23 \\
22 \\
24 \\
24 \\
23\end{array}$ & $\begin{array}{r}11 \\
10 \\
11 \\
9 \\
11 \\
10 \\
10\end{array}$ \\
\hline $08 / 16 / 84$ & $\begin{array}{l}7.6 \\
7.6 \\
7.7 \\
7.8 \\
7.8 \\
7.9\end{array}$ & $\begin{array}{l}.111 \\
.121 \\
.145 \\
.146 \\
.153 \\
.143\end{array}$ & $\begin{array}{l}.071 \\
.079 \\
.085 \\
.088 \\
.095 \\
.084\end{array}$ & $\begin{array}{l}13 \\
13 \\
13 \\
13 \\
13 \\
13\end{array}$ & . & $\begin{array}{l}24 \\
24 \\
21 \\
22 \\
23 \\
24\end{array}$ & $\begin{array}{r}11 \\
12 \\
11 \\
11 \\
10 \\
9\end{array}$ \\
\hline
\end{tabular}




\section{REFERENCES CITED}

Brown, W.M., III, Nowlin, J.O., Smith, L.H., and Flint, M.R., 1986, River-quality assessment of the Truckee and Carson River systems, California and Nevada--Hydrologic characteristics: U.S. Geological Open-File Report 84-576, 201 p.

Canter, L.W., and Knox, R.C., 1986, Septic tank system effects on ground water quality: Chelsea, Mich., Lewis Publishers, 336 p.

Dorich, R.A., Nelson, D.W., and Sommers, L.E., 1980, Algal availability of sediment phosphorus in drainage water of the Black Creck watershed: Journal of Environmental Quality, v. 9, no. 4, p. 557-563.

Feltz, H.R., 1984, Significance of bottom material data in evaluating water quality, in Baker, R.A., ed., Contaminants and sediments: Ann Arbor, Mich., Ann Arbor Science Publishers, v. 1, chap. 11, p. 271-287.

Ferguson, J.F., and Gavis, Jerome, 1972, A review of the arsenic cycle in natural waters:

Water Research, v. 6, p. 1259-1274.

Frisbie, H.R., La Camera, R.J., Riek, M.M., and Wood, D.B., 1985, Water resources data for Nevada, water year 1984: U.S. Geological Survey Water-Data Report NV-84-1, 247 p.

Froelich, P.N., 1988, Kinetic control of dissolved phosphate in natural rivers and estuaries--a primer on the phosphate buffer mechanism: Limnology and Oceanography, v. 33, no. 4, pt. 2, p. 649-665.

Guy, H.P., and Norman, V.W., 1970, Field methods for measurement of fluvial sediment: U.S. Geological Survey Techniques of Water-Resources Investigations, Book 3, Chapter C2, $59 \mathrm{p}$.

Hem, J.D., 1985, Study and interpretation of the chemical characteristics of natural water ( $3 \mathrm{~d}$ ed.):

U.S. Geological Survey Water-Supply Paper 2254, 263 p.

Kcup, L.E., 1968, Phosphorus in flowing waters: Water Research, v. 2, p. 373-386.

La Camera, R.J., Hoffman, R.J., Nowlin, J.O., Smith, L.H., and Lima, S.M., 1985, Data on surface-water quality and quantity, Truckee River system, California and Nevada, 1979-81: U.S. Geological Survey Open-File Report 84-238, 191 p.

Nowlin, J.O., 1987, Modeling nutrient and dissolved-oxygen transport in the Truckee River and Truckee Canal downstream from Reno, Nevada: U.S. Geological Survey Water-Resources Investigations Report 87-4037, 487 p.

Pacific Environmental Laboratory, 1979, Effects of the Reno-Sparks joint water-pollution control plant on water quality of the Truckee River--Summary report: Pacific Environmental Laboratory, San Francisco, draft data report, 489 p.

Paul, John, 1967, Cell biology--A current summary: Stanford, Calif., Stanford University Press, 197 p. 
Skougstad, M.W., Fishman, M.J., Friedman, L.C., Erdmann, D.E., and Duncan, S.S., eds., 1979, Methods for determination of inorganic substances in water and fluvial sediments: U.S. Geological Survey Techniques of Water-Resources Investigations, Book 5, Chapter A1, 626 p.

Strickland, J.D.H., and Parsons, T.R., 1968, A practical handbook of seawater analysis: Fisheries Research Board of Canada, Bulletin 167, 311 p.

Stumm, W., and Leckie, J.O., 1971, Phosphate exchange with sediments--Its role in the productivity of surface waters, in Jenkens, S.H., ed., Advances in water pollution research: Sec. III, v. 2, no. 26, p. 1-16.

U.S. Environmental Protection Agency, 1984, Final environmental impact statement, master project facilities plan, expansion of Reno-Sparks joint water pollution control plant: U.S. Environmental Protection Agency, EPA-9-CA-C-32-0114, 126 p. with 6 numbered appendices.

U.S. Geological Survey, 1977, National handbook of recommended methods for water-data acquisition: Office of Water Data Acquisition, Chap. III, $100 \mathrm{p}$. 